Biogeosciences, 10, 3901-3916, 2013

www.biogeosciences.net/10/3901/2013/

doi:10.5194/bg-10-3901-2013

(C) Author(s) 2013. CC Attribution 3.0 License.

\title{
Phosphorus recycling in sediments of the central Baltic Sea
}

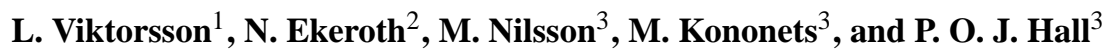 \\ ${ }^{1}$ University of Gothenburg, Department of Earth Sciences, Sweden \\ ${ }^{2}$ Stockholm University, Department of Ecology, Environment and Plant Sciences, Sweden \\ ${ }^{3}$ University of Gothenburg, Department of Chemistry and Molecular Biology, Marine Chemistry, Sweden \\ Correspondence to: L. Viktorsson (lenav@gvc.gu.se)
}

Received: 11 October 2012 - Published in Biogeosciences Discuss.: 2 November 2012

Revised: 21 April 2013 - Accepted: 30 April 2013 - Published: 17 June 2013

\begin{abstract}
Benthic fluxes of phosphorus (P) were measured in situ in the Eastern Gotland Basin (EGB), central Baltic Sea, using benthic landers. A total of 40 flux measurements of dissolved inorganic P (DIP) on 13 stations at water depths ranging 30-210 $\mathrm{m}$ and under different oxygen regimes were carried out on three cruises during three consecutive years (2008-2010) in August-September. Our study is the first to report in situ DIP fluxes in the Baltic proper, and it provides the most comprehensive dataset of benthic fluxes of DIP and dissolved organic P (DOP) in the Baltic proper existing to date. DIP fluxes increased with increasing water depth and with decreasing bottom water oxygen concentration. Average DIP fluxes were calculated for oxic bottom water conditions $\left(-0.003 \pm 0.040 \mathrm{mmolm}^{-2} \mathrm{~d}^{-1}\right)$, hypoxic conditions $\left(0.027 \pm 0.067 \mathrm{mmolm}^{-2} \mathrm{~d}^{-1}\right)$ and anoxic conditions $\left(0.376 \pm 0.214 \mathrm{mmol} \mathrm{m}^{-2} \mathrm{~d}^{-1}\right)$. The mean DIP flux at anoxic bottoms was higher than previous estimates based on ex situ measurements of pore water gradients. The DIP flux was positively correlated with the organic carbon inventory of sediment, and the benthic flux of dissolved inorganic carbon (DIC) at anoxic stations, but these variables were uncorrelated at oxic stations. The positive correlation between DIP and DIC fluxes suggests that the benthic DIP efflux from anoxic bottoms in the Baltic Proper is mainly controlled by rates of deposition and degradation of organic matter. The flux from anoxic sediment was very $\mathrm{P}$ rich in relation to both $\mathrm{C}$ and nitrogen $(\mathrm{N})$. The average $\mathrm{C}: \mathrm{P}$ ratio in fluxes at anoxic accumulation bottoms was $69 \pm 15$, which is well below the Redfield C : $\mathrm{P}$ ratio of $106: 1$. At oxic stations, however, the $\mathrm{C}: \mathrm{P}$ flux ratio was much higher than the Redfield ratio, consistent with well-known $\mathrm{P}$ retention mechanisms associated with iron and bacteria in oxidised sediment. Using a benthic mass balance approach, a burial efficiency estimate of
\end{abstract}

$0.2-12 \%$ was calculated for the anoxic part of the EGB, which suggests that anoxic Baltic sediments are very efficient in recycling deposited P. Based on the measured fluxes and the average areal extent of anoxic bottoms during years

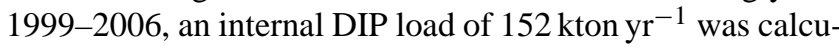
lated. This is almost 9 times higher than the average external total phosphorus (TP) supply to the Baltic proper during the same period. This comparison clearly highlights the dominance of internally regenerated $\mathrm{P}$ as a DIP source in the Baltic Sea.

\section{Introduction}

Phosphorus $(\mathrm{P})$ is a major and vital component of the biosphere. The biogeochemical cycling of this element has, therefore, attracted scientific study for almost a century. It has been long known that primary production is often ratelimited by the amount of bioavailable $\mathrm{P}$ in aquatic environments, especially in fresh water lakes (Schindler, 1977). Phosphorus limitation also occurs in coastal marine and oceanic systems (Granéli et al., 1990; Krom et al., 1991; Wu et al., 2000). One example is the Baltic Sea, a brackish semienclosed eutrophicated sea area in northern Europe constituting a total area of about $377000 \mathrm{~km}^{2}$ (Elmgren, 2001). Nutrient limitation in the southernmost and largest water body of the Baltic Sea, the Baltic proper, generally shifts seasonally; after the N-limited spring bloom has settled out, the system becomes limited by $\mathrm{P}$ as diazotrophic cyanobacteria begin to dominate the phytoplankton community (Granéli et al., 1990; Hagström et al., 2001; Nausch et al., 2008).

The frequency at which massive cyanobacterial blooms develop is reported to have increased over the last $50 \mathrm{yr}$ in 
the Baltic Sea (Finni et al., 2001; Poutanen and Nikkilä, 2001). This is most likely an effect of the sharp increase of the winter water dissolved inorganic phosphorus (DIP) concentration that occurred between 1965 to 1985 in the Eastern Gotland, Arkona and Bornholm Basins (Finni et al., 2001; Nausch et al., 2008; Eilola et al., 2009). Cyanobacterial Nfixation adds new nitrogen to the system in roughly equal amounts to the total riverine input (Larsson et al., 2001). Hence, diazotrophic cyanobacteria are not only a sign of, but also conducive to, eutrophication of the Baltic Sea (Voss et al., 2011).

During periods when the area of anoxic bottom sediment is expanding in the Baltic proper, deoxygenated bottom sediments constitute a net source of $\mathrm{P}$ to the bottom water. In extreme cases, more than $100 \mathrm{kton} P$ can be supplied to the water in a single year when the area of hypoxic/anoxic sediment increases (Conley et al., 2002). External P sources to the Baltic proper have declined since the mid 1980s and varied between ca. 12-20 kton total P (TP) $\mathrm{yr}^{-1}$ for the years 1994-2008 (HELCOM, 2011). Emeis et al. (2000) quantified that between 1970-1994 $14 \mathrm{kton} \mathrm{yr}^{-1}$ of excess $\mathrm{P}$ was supplied to the water from deep long-term anoxic sediments in the Eastern Gotland Basin (EGB) due to the fractionation towards $\mathrm{P}$ in the remineralisation of organic matter. Their calculation was based on the difference in $\mathrm{C} / \mathrm{P}$ ratios between sedimenting particulate matter and solid sediment accumulated during that time. Thus, a positive feedback mechanism has been proposed where surface water nutrient enrichments result in increased sedimentation of organic matter, bottom water oxygen depletion and increased sedimentary $P$ release back to the water column (Emeis et al., 2000; Vahtera et al., 2007).

Rising $\mathrm{P}$ concentrations in the benthic efflux at the onset of bottom water hypoxia/anoxia is often ascribed to the biogeochemical reduction and dissolution of P-rich Fe oxyhydroxide particles $(\mathrm{Fe}-\mathrm{P})$ in the sediment (Gunnars and Blomqvist, 1997; McManus et al., 1997). Conversely, the reformation of a Fe-P pool in the sediment due to oxygenation of the bottom water typically results in an increased sedimentary $\mathrm{P}$ retention. These DIP mobilisation/immobilisation processes may also be related to bacterial phosphate assimilation which, when the oxygen regime is oscillating, is high during oxic periods. Polyphosphate stored during oxic conditions is hydrolysed and released as phosphate during anoxia, when it is utilised in the anaerobic energy metabolism, or following the death and degradation of the bacteria themselves (Gächter and Meyer, 1993).

The nutrient efflux from long-term anoxic sediments generally remains enriched in P compared to carbon (C) and dissolved inorganic nitrogen (DIN) (Schneider et al., 2002; Jilbert et al., 2011; Viktorsson et al., 2012). Such preferential regeneration of $\mathrm{P}$ cannot be explained by the aforementioned processes that cause increased benthic DIP release during seasonal or short term anoxia, as the pool of redox mobile P has long been depleted (c.f. Mort et al., 2010). However, the mechanism(s) involved in the preferential regeneration of $\mathrm{P}$ under long-term anoxic conditions remain enigmatic. Recent evidence suggests, however, that microbial phosphatases could be an important part of the explanation (Steenbergh et al., 2011). Phosphatases, enzymes which cleave off phosphate groups from organic matter, are used by C-limited bacteria to increase the bioavailability of the organic matter $\mathrm{C}$ moiety (Steenbergh et al., 2011, and references therein). Under anoxic conditions, the phosphate liberated by the phosphatases diffuse out into the bottom water to a much larger degree than in oxic sediments where a substantial proportion is trapped in surficial oxidised sediment layers (Steenbergh et al., 2011) through bacterial phosphate assimilation and $\mathrm{Fe}$ scavenging.

It is clear that the exchange of $\mathrm{P}$ across the sedimentwater interface has a major influence on the magnitude of the bioavailable P pool in the Baltic Sea. However, direct measurements of this exchange are scarce, especially in open sea areas.

One aim of this paper was to quantify the benthic $\mathrm{P}$ flux under natural bottom water oxygen conditions. We worked on stations transecting the EGB (central Baltic proper) from shallow oxygenated transport bottoms on the western side via anoxic/sulfidic deep accumulation bottoms to shallow oxygenated sandy bottoms on the eastern side of the EGB. We measured fluxes in situ with autonomous benthic landers. Sediment investigations involved pore water and solid phase nutrient analyses. Furthermore, we provide new estimates of the integrated benthic $P$ regeneration flux (the internal DIP load) on a basin-wide (Baltic proper) scale, and of the $\mathrm{P}$ burial efficiency for anoxic sediments. This paper is the first to report in situ measured benthic P fluxes in the open Baltic proper.

\section{Materials and methods}

\subsection{Study site}

The largest basin of the Baltic Sea is the Baltic proper, which consists of a number of sub-basins, namely, the Western Gotland, Eastern Gotland, Gdansk, Bornholm and Arkona basins. A permanent halocline is present in the Baltic proper at 60-80 m depth (Stigebrandt, 2001). The sub-halocline water mass, which is hypoxic-anoxic (hypoxic is here defined as $\mathrm{O}_{2} \leq 91.4 \mu \mathrm{M}$ or $2 \mathrm{mLL}^{-1}$ ), constitutes about $30 \%$ of the total volume and it is only rarely replaced by oxygenated saltier water by inflows from the Kattegat (Stigebrandt and Wulff, 1987). The catchment area of the Baltic Proper is $575000 \mathrm{~km}^{2}$ and comprises 12 countries (HELCOM, 2004).

This study was carried out in the major basin of the Baltic proper, the EGB with a maximum depth of $249 \mathrm{~m}$ (the Gotland Deep). The EGB is surrounded by the island of Gotland in the west, Latvia and Lithuania in the east, Estonia in the north-east and Poland in the south. The eastern part 


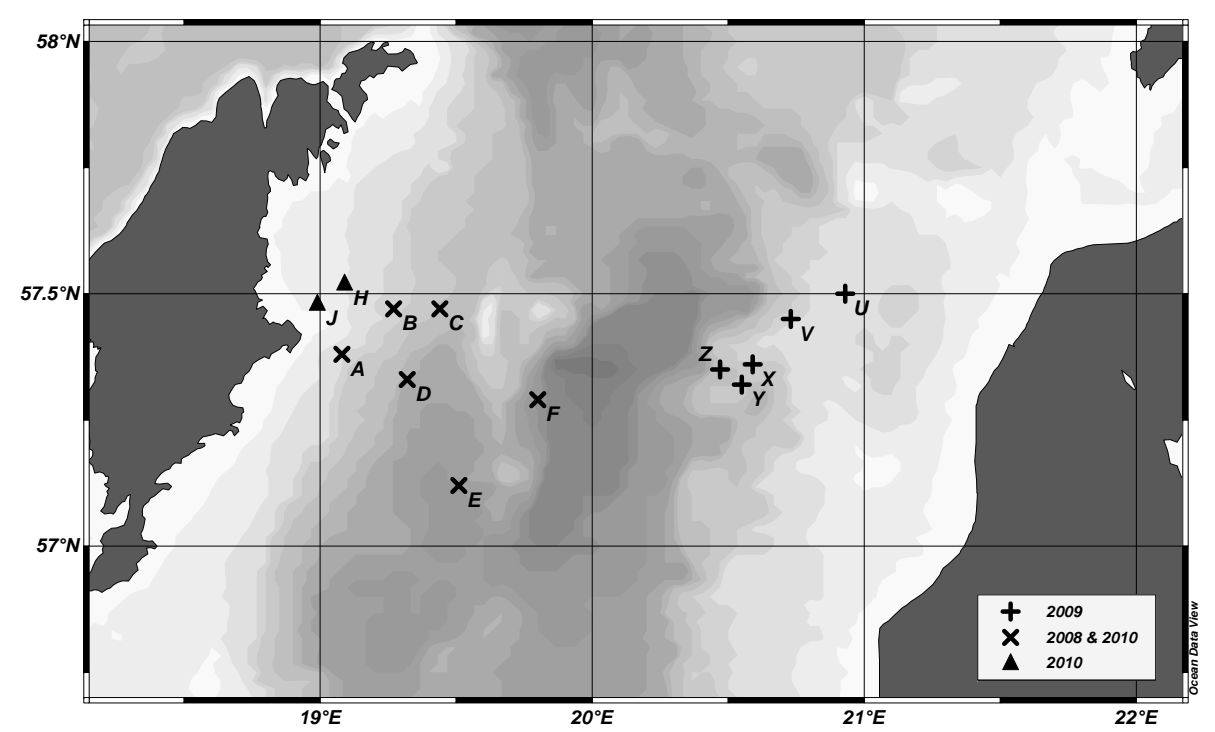

Fig. 1. Map of the central part of the Eastern Gotland Basin. Visited stations are indicated by a cross (2009 cruise), a triangle (2010 cruise only) and an $\mathbf{x}$ (2008 and 2010 cruises). Positions and water depths are given in Table 1.

of the EGB is strongly influenced by winds, wave action and bottom stress. The sediments are, therefore, strongly reworked making them sandy, and they are often classified as erosion or transportation bottoms (E or T bottoms). Sediments of the central and western part of the basin close to the island of Gotland is less reworked due to its more wind and wave protected location, making more particles settle even on shallower depths and sediments here, therefore, consist of clayey/silty material. Accumulation bottoms (A bottoms) are more frequent in this area. According to Carman and Cederwall (2001), $38 \%$ of the Baltic proper consists of A-bottoms, $38 \%$ of T-bottoms and $24 \%$ are E-bottoms.

Three expeditions were conducted; in September 2008, September 2009 and August 2010. In total, data was collected from 13 stations in the EGB of which five were visited on two different expeditions, and several stations were visited more than once on each expedition. A description of the stations is presented in Table 1 . The stations were located in an east-west transect across the EGB, including stations with both oxic and anoxic bottom water (Fig. 1). Station bottom depths ranged from $30 \mathrm{~m}$ (station $\mathrm{J}$ ) to $210 \mathrm{~m}$ (station F). Stations D, E, F, Y and Z were located at greater depths $(>124 \mathrm{~m})$, and considered to be long-term anoxic. Stations A, J, H and U were located shallower, above the halocline and they were permanently oxic. Stations B, C, V and $X$ were located in a depth range $(75-90 \mathrm{~m})$ with shifting (i.e., changing between oxic and anoxic) bottom water oxygen conditions. At these stations the bottom water oxygen concentration ranged from 3 to $36 \mu \mathrm{M}$ with the exception of station B in 2008 when it was $125 \mu \mathrm{M}$ (Table 1).

\subsection{Sediment sampling}

Sediment cores were collected with a Multiple Corer, MUC (Barnett et al., 1984). The MUC was equipped with $55 \mathrm{~cm}$ long Plexiglas tubes with an inner diameter of $9.9 \mathrm{~cm}$. Only cores with minimal sampling disturbance were used, indicated by clear overlying water, appearance of a fluffy layer or bacterial mats (Beggiatoa spp.) at the sediment-water interface and/or undisturbed laminas in anoxic sediments. Cores were sliced in $0.5,1$ and $2 \mathrm{~cm}$ thick intervals down to a sediment depth of $20 \mathrm{~cm}$ with the highest vertical resolution in the upper part of the core. Cores were sliced instantly after recovery to minimise contact with atmospheric oxygen and other recovery artifacts. Cores that were used for porewater sampling were handled under anoxic conditions using a "glove bag" (Aldrich Atmosbag, Sigma Aldrich) filled with and under continuous flow of nitrogen gas. Different samples were taken from each core and were saved for later treatment and analysis; see methods below. Parameters determined in the solid phase were organic carbon $\left(\mathrm{C}_{\text {org }}\right)$, total phosphorus (TP) and water content (WC).

Pore water was extracted by means of centrifugation at 2500-3000 rpm (about $670 \mathrm{G}$ ) for $30 \mathrm{~min}$. The pore water was filtered $(0.45 \mu \mathrm{m}$ nominal pore size cellulose acetate filters, pre-cleaned in MQ water) and saved for later analysis of dissolved inorganic phosphorus (DIP), dissolved iron (DFe) and dissolved manganese (DMn). The pore water samples for $\mathrm{Fe}$ and $\mathrm{Mn}$ were acidified with ultrapure $30 \%$ hydrochloric acid to avoid oxidation artifacts. The pore water samples for DIP were not acidified, since that may cause hydrolysis of soluble non-reactive $\mathrm{P}$ compounds (e.g. poly-phosphate; Koroleff, 1983) in the samples, and hence an artificial generation of additional DIP. 
Table 1. Description of stations. The water content is the mass percent in the uppermost centimetre of the sediment. The bottom types A, $\mathrm{T}$ and E refers to Accumulation, Transportation and Erosion bottoms, respectively (Håkanson and Jansson, 2002). Temperature and salinity were measured in ambient bottom water (BW); averages are shown when more than one deployment was made at the same station. The bottom water $\mathrm{O}_{2}$ concentration, in $\mu \mathrm{M}$, was measured approximately $10-20 \mathrm{~cm}$ above bottom with an optode inside each chamber just before start of incubation (except at stations X and Z, where it was measured with a Seabird SBE 911 sensor on the CTD); the values given are mean values from 2-12 chambers depending on how many deployments were made at the same station the same year; the number of chambers used are given in the last column, $n$. ND means no sediment coring in 2010 at the station J.

\begin{tabular}{|c|c|c|c|c|c|c|c|c|c|c|}
\hline \multirow{2}{*}{$\begin{array}{l}\text { Year, } \\
\text { month }\end{array}$} & \multirow[t]{2}{*}{ station } & \multirow{2}{*}{$\begin{array}{l}\text { depth } \\
{[\mathrm{m}]}\end{array}$} & \multicolumn{2}{|c|}{ Position } & \multirow{2}{*}{$\begin{array}{l}\text { Sediment } \\
\text { water } \\
\text { content } \\
{[\% \mathrm{WM}]}\end{array}$} & \multirow{2}{*}{$\begin{array}{l}\text { Bottom } \\
\text { type }\end{array}$} & \multirow{2}{*}{$\begin{array}{c}\mathrm{BW} \\
\mathrm{T} \\
{\left[{ }^{\circ} \mathrm{C}\right]}\end{array}$} & \multirow{2}{*}{$\begin{array}{c}\text { BW } \\
\text { S }\end{array}$} & \multirow{2}{*}{$\begin{array}{c}\mathrm{BW} \\
\mathrm{O}_{2} \\
{[\mu \mathrm{M}]}\end{array}$} & \multirow[t]{2}{*}{$n$} \\
\hline & & & Lat. N & Lon. E & & & & & & \\
\hline 2008 & A & 60 & $57^{\circ} 23.06^{\prime}$ & $19^{\circ} 05.02^{\prime}$ & 39 & $\mathrm{E}$ & 4.4 & 7.5 & $284 \pm 6$ & 4 \\
\hline SEP & B & 75 & $57^{\circ} 28.34^{\prime}$ & $19^{\circ} 16.00^{\prime}$ & 82 & A & 4.6 & 8.7 & $125 \pm 11$ & 3 \\
\hline \multirow[t]{4}{*}{16 th to 26 th } & $\mathrm{C}$ & 90 & $57^{\circ} 28.04^{\prime}$ & $19^{\circ} 26.01^{\prime}$ & 69 & $\mathrm{~T}$ & 5.3 & 10.0 & $6 \pm 1$ & 3 \\
\hline & $\mathrm{D}$ & 129 & $57^{\circ} 19.65^{\prime}$ & $19^{\circ} 19.26^{\prime}$ & 95 & A & 6.2 & 12.0 & anoxic & 4 \\
\hline & $\mathrm{E}$ & 170 & $57^{\circ} 07.45^{\prime}$ & $19^{\circ} 30.60^{\prime}$ & 93 & A & 6.3 & 12.6 & anoxic & 4 \\
\hline & $\mathrm{F}$ & 210 & $57^{\circ} 17.24^{\prime}$ & $19^{\circ} 48.02^{\prime}$ & 94 & A & 6.3 & 12.7 & anoxic & 4 \\
\hline 2009 & $\mathrm{U}$ & 49 & $57^{\circ} 30.01^{\prime}$ & $20^{\circ} 56.03^{\prime}$ & 24 & E & 6.0 & 7.6 & $191 \pm 4$ & 3 \\
\hline SEP 20th to & V & 64 & $57^{\circ} 26.50^{\prime}$ & $20^{\circ} 43.62^{\prime}$ & 55 & $\mathrm{~T}$ & 4.7 & 9.4 & $36 \pm 4$ & 2 \\
\hline \multirow[t]{3}{*}{ OCT 1st } & $\mathrm{X}$ & 90 & $57^{\circ} 20.73^{\prime}$ & $20^{\circ} 35.35^{\prime}$ & 94 & A & 6.4 & 11.0 & $0-3$ & 0 \\
\hline & $\mathrm{Y}$ & 124 & $57^{\circ} 18.87^{\prime}$ & $20^{\circ} 33.07^{\prime}$ & 90 & A & 6.6 & 11.3 & anoxic & 4 \\
\hline & $\mathrm{Z}$ & 170 & $57^{\circ} 20.86^{\prime}$ & $20^{\circ} 28.34^{\prime}$ & 95 & A & 6.7 & 12.1 & anoxic & 0 \\
\hline 2010 & $\mathrm{~J}$ & 30 & $57^{\circ} 28.83^{\prime}$ & $18^{\circ} 59.51^{\prime}$ & ND & ND & 4.5 & 7.4 & $274 \pm 4$ & 2 \\
\hline AUG 16th to & $\mathrm{H}$ & 44 & $57^{\circ} 31.11^{\prime}$ & $19^{\circ} 05.25^{\prime}$ & 30 & $\mathrm{E}$ & $2.9 \pm 0.1$ & $7.8 \pm 0.1$ & $248 \pm 17$ & 12 \\
\hline \multirow[t]{5}{*}{ SEP 2nd } & A & 59 & $57^{\circ} 23.11^{\prime}$ & $19^{\circ} 04.92^{\prime}$ & 58 & $\mathrm{~T}$ & $4.2 \pm 0.1$ & $8.4 \pm 0.9$ & $164 \pm 60$ & 7 \\
\hline & B & 75 & $57^{\circ} 28.36^{\prime}$ & $19^{\circ} 16.26^{\prime}$ & 88 & A & 5.5 & $9.9 \pm 0.1$ & $2 \pm 2$ & 4 \\
\hline & $\mathrm{D}$ & 128 & $57^{\circ} 19.65^{\prime}$ & $19^{\circ} 19.29^{\prime}$ & 91 & A & 6.8 & 12.0 & anoxic & 4 \\
\hline & $\mathrm{E}$ & 170 & $57^{\circ} 07.43^{\prime}$ & $19^{\circ} 30.60^{\prime}$ & 94 & A & 6.5 & 12.3 & anoxic & 4 \\
\hline & $\mathrm{F}$ & 210 & $57^{\circ} 17.23^{\prime}$ & $19^{\circ} 48.02^{\prime}$ & 94 & A & 6.4 & 12.45 & anoxic & 4 \\
\hline
\end{tabular}

\subsection{In situ chamber incubations with the Göteborg benthic landers}

Two landers were used during this study, the big and small Göteborg landers. The big Göteborg benthic lander is a fully autonomous instrument that can operate on the seafloor down to $6000 \mathrm{~m}$ depth without any contact with the ship or the surface (Ståhl et al., 2004; Almroth et al., 2009). The big lander is equipped with four incubation chamber modules. The small Göteborg lander is a simplified version of the big lander. The small lander must be deployed with a rope for recovery, using a surface buoy, or by dredging. The small lander has two incubation chamber modules, identical to those installed on the big lander. For incubation, each chamber encloses a $400 \mathrm{~cm}^{2}$ area of the sediment surface together with overlying bottom water. The incubated water is stirred by a horizontal paddle wheel placed centrally inside the chamber to prevent the development of concentration gradients in the chamber (Tengberg et al., 2004). Each chamber carries ten syringes for injection or water sampling. Nine syringes were used for sampling chamber water at pre-set times making it possible to measure solute fluxes across the sediment- water interface. The tenth syringe was used to inject a small and known volume of MQ water (about $60 \mathrm{~mL}$, corresponding to less than $0.5 \%$ of total chamber volume). Based on the resulting salinity change, measured by a conductivity sensor, the chamber volume could then be calculated, as described by Nilsson (2008). To make sure ambient bottom water was incubated above sediment in the chambers, and to avoid oxygen dissolved in the polycarbonate of which the chambers are made to contaminate anoxic incubations, the chambers were hanging above the sea-floor for several hours with the lids open and stirring on before they were inserted into sediment, lids closed and incubations started.

The duration of the incubations were typically $15-36 \mathrm{~h}$ depending on flux rates. Oxygen concentrations were measured in each chamber with 1-min intervals using oxygen optodes, model 3830 (the big lander) or 3835 (the small lander) from Aanderaa Data Instruments, Norway (Tengberg et al., 2006). Measurements of conductivity for chamber volume control and leakage detection were made with conductivity sensors model 3919A (Aanderaa Data Instruments, Norway). Conductivity was measured in each chamber at 1-min interval. Immediately after the landers were recovered, water samples 
were taken from each of the nine syringes in each chamber. The water was filtered through pre-cleaned $0.45 \mu \mathrm{m}$ pore size cellulose acetate filters and stored dark and cold for later analysis.

\subsection{Analytical methods}

\subsubsection{DIP, TDP, DFe and DMn}

TDP samples were digested with acid-persulphate at high temperature (modified after Valderrama, 1981). The dissolved organic P (DOP) concentration was operationally defined as the concentration difference between TDP and DIP samples. All P samples were stored dark and cool and after each expedition sent for analysis according to a standard method using Segmented Flow Analysis (SFA), modified after Koroleff (1983). The analytical precision for DIP was $\pm 0.5 \mu \mathrm{g} \mathrm{PL}^{-1}$ for low concentrations $\left(0.5-20 \mu \mathrm{g} \mathrm{PL}^{-1}\right)$ and $\pm 3 \%$ for concentrations over $20 \mu \mathrm{gL}^{-1}$. The analytical precision for TDP was $\pm 1 \mu \mathrm{PL}^{-1}$ for low concentrations $\left(0.5-25 \mu \mathrm{gL}^{-1}\right)$ and $\pm 6 \%$ for concentrations over $25 \mu \mathrm{PL}^{-1}$. The analytical precision for DOP was defined as the root of the squared sums of the DIP and TDP precisions.

Dissolved iron (DFe) and manganese (DMn) in pore water were determined photometrically using ferrozine and formaldoxyme procedures, respectively (Peshkova and Ovsyannikova, 1937; Grasshoff et al., 1999; Kononets et al., 2002; Pakhomova, 2005). The limit of detection was 0.07 and $0.03 \mu \mathrm{M}$ for $\mathrm{Mn}$ and $\mathrm{Fe}$, respectively, using a $5-\mathrm{cm}$ cell.

\subsubsection{Sediment physical properties}

The sediment WC (mass percent in the top centimetre) was used to determine the bottom type (A, T or E type) at each station. According to Håkanson and Jansson (2002) sediment with $\mathrm{WC}<50 \%$ represent erosion bottoms while WC $>75 \%$ define accumulation bottoms. Transportation bottoms are the intermediates. The sediment WC was obtained from the weight loss after drying at $78^{\circ} \mathrm{C}$ until constant weight, usually about $2-3$ days.

\subsubsection{Sediment geochemical properties}

Determination of organic carbon (Corg) in sediment was carried out by gas chromatography. The sediment was first freeze-dried until constant mass, ground and treated with fumes of $\mathrm{HCl}(37 \%$ for at least $48 \mathrm{~h})$ to remove inorganic carbon. A small fraction of known weight (10-20 mg) was then analysed in a Carlo ERBA N1500g gas chromatograph. The instrument and method are described in detail by Verardo et al. (1990). The precision for Corg was $\pm 1 \%$.

From the same freeze-dried and carefully ground sediment sample, a small portion was used for TP determination. Sediment samples were then pre-burned at $500^{\circ} \mathrm{C}$ and further oxidised with acidic potassium peroxymonosulfate to get phosphate-P, which was detected with SFA (modified after Koroleff, 1983). The precision was $\pm 5 \%$.

\subsubsection{Calculation of benthic $P$ fluxes}

A least square linear regression of the $P$ concentration against time for each P fraction (DIP and DOP) in each chamber was made from the nine syringe samples. The slope, from the linear regression, times the chamber height (water column height; obtained from determination of chamber volume) gives the net increase or decrease in the chamber $P$ content, per time and area. These are the benthic DIP and DOP fluxes which are reported in $\mathrm{mmol} \mathrm{m}^{-2} \mathrm{~d}^{-1}$ in this paper. Fluxes were approved to be significant if the $p$ value of the linear regression was $\leq 0.05$. However, since very low or zero fluxes are difficult to measure, a second condition was needed to avoid biasing towards high fluxes. If the flux was not significant according to the first condition $(p \leq 0.05)$, the absolute concentration change, determined from the linear regression, was compared to the analytical precision (given in analytical methods section above). If the absolute concentration change was less than the analytical precision, the flux was set to zero; otherwise it was considered non-significant and rejected from the data analysis.

\section{Results}

\subsection{Sediment total phosphorus}

Total phosphorus was analysed in sediment samples from stations A-08, B-08, C-08, E-08 and F-08 (see Table 1 for description of stations) visited in year 2008. The TP inventory in the upper $0-2 \mathrm{~cm}$ of the sediment generally increased with water depth (Fig. 2), as did Corg and total nitrogen (TN) inventories (Nilsson et al., 2013). The TP inventory in the upper two centimetres of sediment was higher at the deep anoxic accumulation bottom than at the shallower bottoms (which most often were transportation or erosion bottoms). Below a depth of ca. $5 \mathrm{~cm}$, the sediment TP concentration was similar at all stations. At the deep anoxic stations (E-08 and F-08), TP concentrations decreased with sediment depth down to $5 \mathrm{~cm}$, but remained unchanged in the $5-19 \mathrm{~cm}$ sediment depth interval. At the shallow stations A-08, B-08 and C-08, the TP concentration decreased sharply in the first few $\mathrm{cm}$ to reach a minimum at $1.5-2 \mathrm{~cm}$ sediment depth. Below this zone, the TP content again increased to a stable value of ca. $30 \mu \mathrm{molg}^{-1}$ (Fig. 2). This value probably reflects the $\mathrm{P}$ content of the postglacial clay (see below).

\subsection{Pore water DIP, DFe and DMn}

Dissolved inorganic phosphorus (DIP) in the pore water was measured at stations with water depths ranging from $59 \mathrm{~m}$ to $210 \mathrm{~m}$ (Fig. 3). Pore water DIP concentrations from the deepest stations (124-210 m) generally increased with sediment 

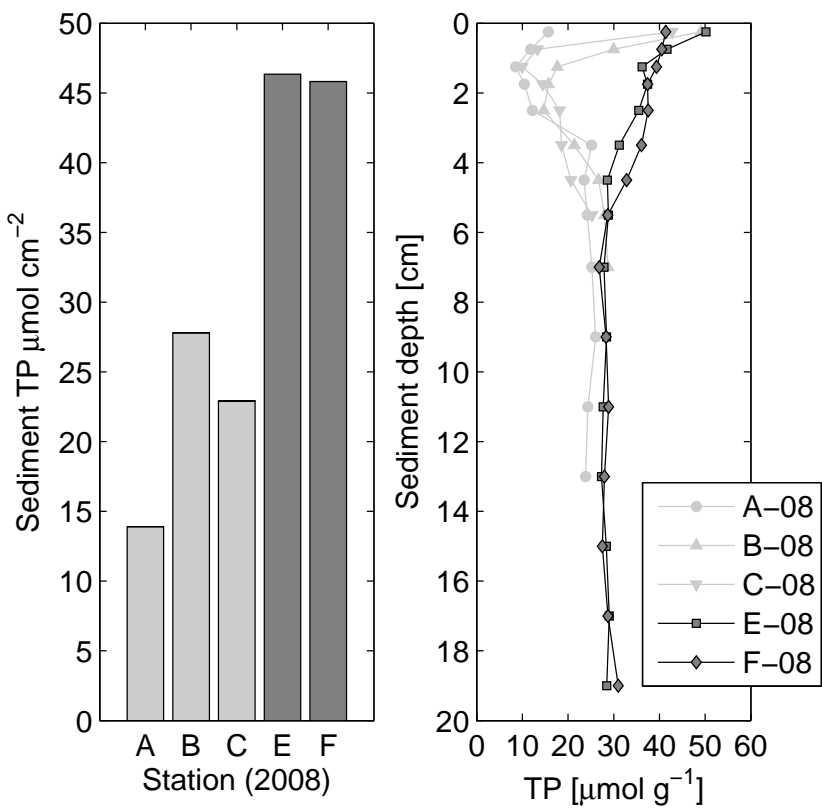

Fig. 2. Total phosphorus (TP) inventory $(0-3 \mathrm{~cm})$ (left panel) and profiles (right panel) in sediment from five stations in the Eastern Gotland Basin 2008. Stations with oxic bottom water are shown in a lighter grey colour and those with anoxic bottom water in a darker grey colour.

depth from near surface values of ca. $5 \mu \mathrm{molL} \mathrm{L}^{-1}$. The nearsurface DIP concentrations were typically lower at the shallower stations (59-90 m) than at the deep stations (Fig. 3). Stations C-08 and X-09, located at ca $90 \mathrm{~m}$ water depth, on the western and eastern side of the basin, respectively, were very different due to differences in sediment properties. The DIP profile from the eastern station X-09, with organic rich clayey sediment, much resembled the profiles from the deeper stations, whereas the DIP profile from station C-08, with sandy sediment that also had gravel and larger stones in it, was similar to the shallower stations.

In 2008, also dissolved Fe and Mn (DFe and DMn) concentrations in pore water were measured (Fig. 4). At the shallow stations (A-08 and B-08), DMn and/or DFe concentrations appeared to co-vary with the DIP concentrations. At the shallow oxic stations, very low concentrations of DFe and DMn were found in the oxidised surface layer below which the concentrations increased to a maximum at about $2 \mathrm{~cm}$ sediment depth at stations A-08 and B-08. At station C08 , the profiles were different, with only minor variations of DFe and DMn, and lower concentrations. At the deep anoxic stations DFe concentrations were low and decreased down the core. DMn concentrations, on the other hand, were as high at the anoxic stations as at the oxic stations, but at the deep anoxic stations DMn either did not change much in the profile (D-08 and E-08, 130 and $170 \mathrm{~m}$ ) or steadily increased down the sediment core $(\mathrm{F}-08,210 \mathrm{~m})$.
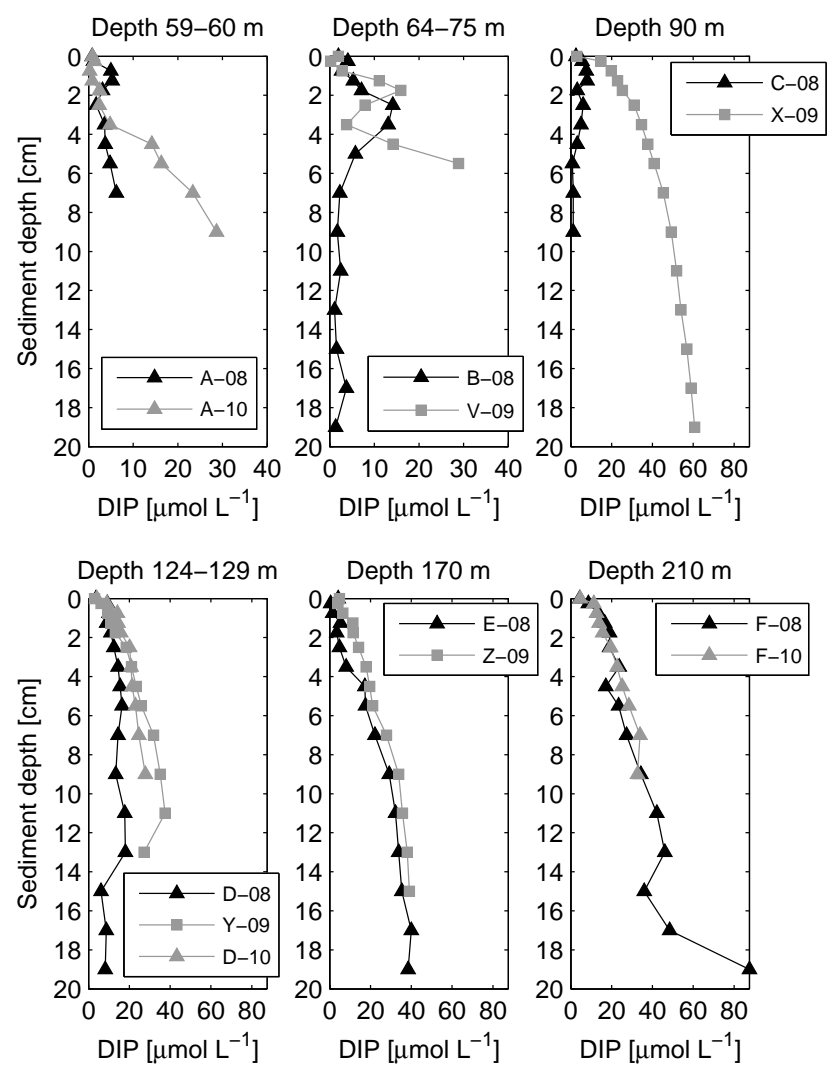

Fig. 3. Pore water DIP profiles at stations $\leq 90 \mathrm{~m}$ (top three panels) and stations $>90 \mathrm{~m}$ (bottom three panels) 2008-2010. Profiles from stations at similar bottom depths are shown together. Note the different scales on the $\mathrm{x}$-axes.

\subsection{Benthic P fluxes}

The proportion of statistically significant DIP fluxes from the in situ incubations was larger at anoxic bottoms compared to at oxic bottoms. This was mainly due to the comparably very low flux rates at oxic bottoms, resulting in small relative changes of the initial $\mathrm{P}$ concentrations inside the chambers during the flux incubations (in spite of longer incubation times at oxic bottoms), which are difficult to capture analytically. For this reason, when evaluating fluxes, we used protocols avoiding biasing towards high DIP fluxes (see Sect. 2.4.4). Less data is also available from oxic bottoms because they are more difficult to incubate for two technical reasons; (i) the coarser sediment (often with shells in it) increases the risk of water leakage into the chamber from the surrounding bottom water, and (ii) the stiffness of the sediment can hinder the chambers to penetrate sufficiently deep into the sediment. Examples of DIP data from chamber incubations at oxic shallow transportation/erosion bottoms and anoxic deep accumulation bottoms are presented in Figs. 5 and 6, respectively. DIP fluxes in general increased with bottom depth and decreased with increasing bottom water oxygen concentration (Fig. 7). Station C-08, where there was an 

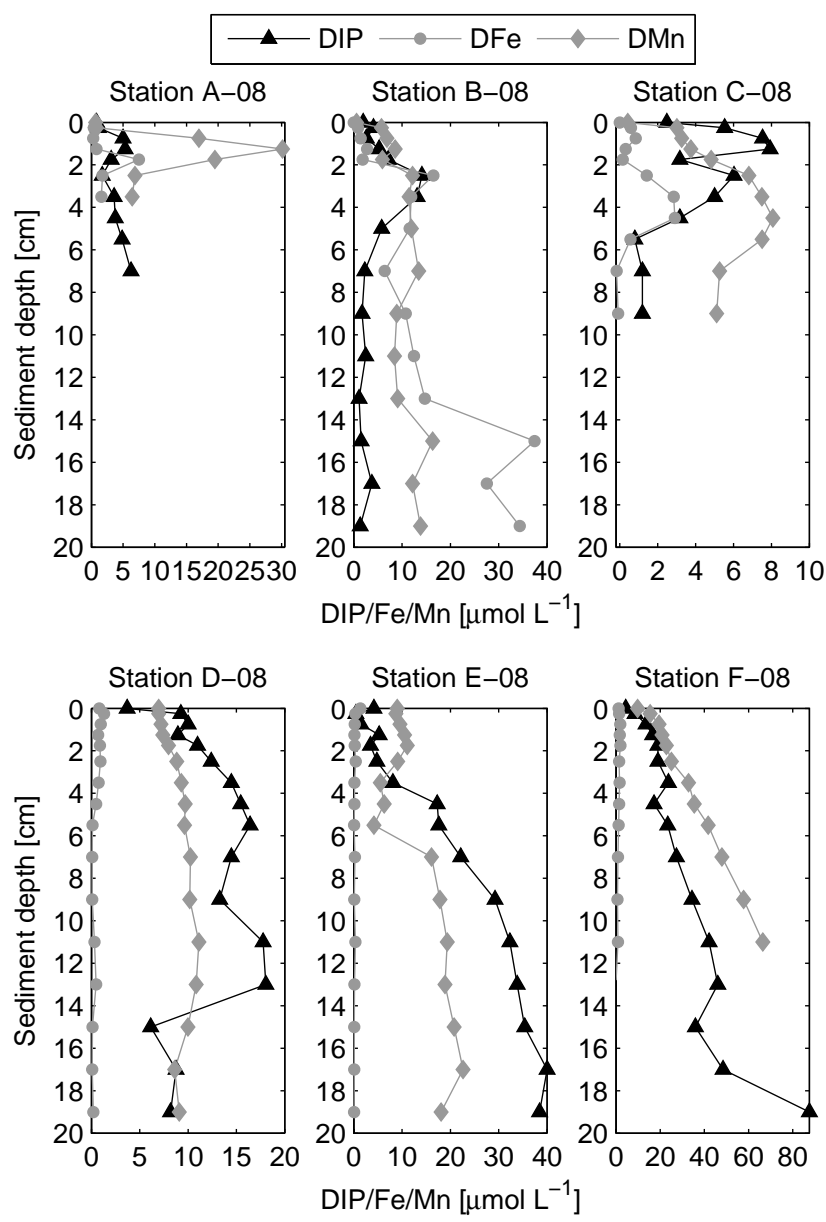

Fig. 4. Total dissolved $\mathrm{Fe}$ and $\mathrm{Mn}$ in pore water, together with profiles of pore water DIP from 2008 (also shown in Fig. 3). Note the different scales on the $\mathrm{x}$-axes.

uptake of DIP despite low bottom water oxygen, is an exception to this general pattern. DOP fluxes were measured during the 2010 expedition at station $\mathrm{H}(44 \mathrm{~m})$ and $\mathrm{D}(128 \mathrm{~m})$. Significant DOP fluxes were only obtained on the former station and they were always directed out of the sediment. The complete set of DIP and DOP flux data is given in the Supplement.

\section{Discussion}

\subsection{Relations between pore water distributions of DIP, DFe, DMn and sediment TP}

The decrease of the sedimentary TP concentrations at the oxic stations (A-08, B-08 and partly C-08) from the surface to $6 \mathrm{~cm}$ depth was likely due to $\mathrm{Fe}(\mathrm{III})$-P adsorption/coprecipitation in the surficial sediment, which is lost with increasing sediment depth and more reducing conditions. The increasing TP concentrations below $6 \mathrm{~cm}$ depth
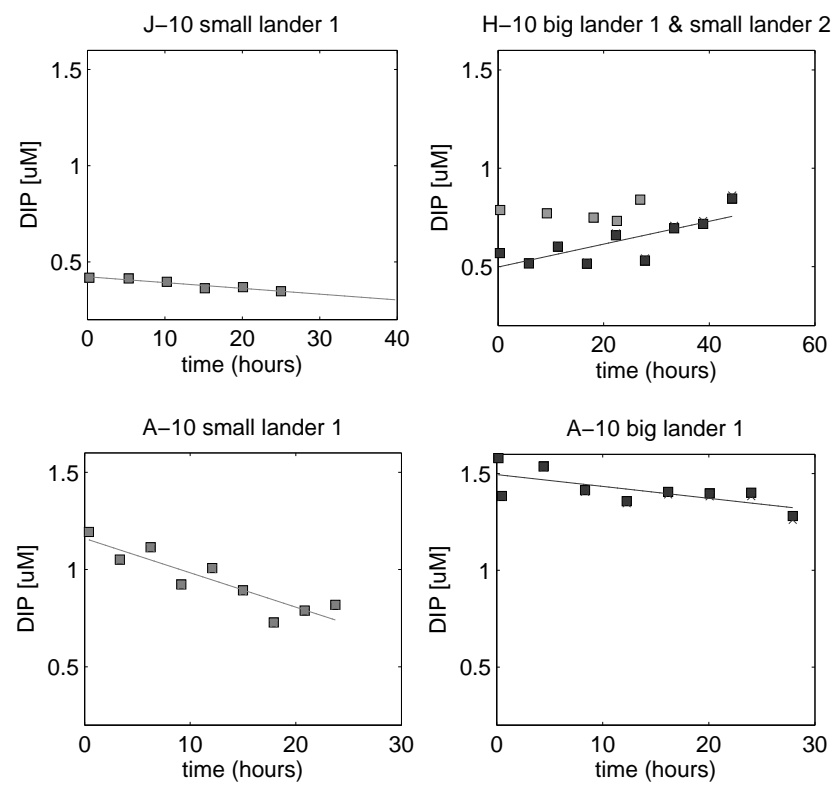

Fig. 5. Examples of evolution of the DIP concentration with time in chambers from oxic stations (J, H, A) on the 2010 cruise. The different shades of grey indicate different chambers. Filled squares indicate data points used to evaluate the flux. A full thin line means that the slope of the linear regression was used to calculate the flux $(p<0.05)$. No line indicates that the increase over time in the chamber was too small to be measurable and the flux was set to zero (the procedure to evaluate chamber data and to calculate fluxes is described in the text).

may be due to higher TP content in the post-glacial clay than in the more recently deposited sediment above the clay. However, it is clear in the upper $2-3 \mathrm{~cm}$ of these profiles that the pore water concentration peaks of DIP, DFe and DMn often coincided (Fig. 4). This suggests that $\mathrm{Fe}$ and/or Mn reduction supplied DIP from the sediment solid phase to the pore water in these sediments. Conversely, the TP enrichment and low concentrations of DFe and DMn near the sediment-water interface at the oxic stations was likely due to scavenging of DIP by bacteria and/or metal oxides in the oxidised sediment layer (c.f. Sundby et al., 1992; Gächter and Meyer, 1993). The TP distributions in sediment at the deeper anoxic stations (D-08, E-08 and F-08) were unrelated to the changes in dissolved metal concentrations. This was expected, as the behaviour of $\mathrm{Fe}, \mathrm{Mn}$ and $\mathrm{P}$ should be uncoupled in surficial sediment under permanently anoxic conditions.

Fe-P particles formed by co-precipitation upon oxidation of $\mathrm{Fe}$ (II) have a molar ratio of $\mathrm{Fe}: \mathrm{P} \geq 2$ (Gunnars and Blomqvist, 1997; Gunnars et al., 2002). Therefore, the pore water Fe : DIP ratio during bottom water anoxia may be used as an indicator for the capacity of newly formed Fe oxyhydroxides to scavenge DIP upon (re)oxygenation. The average molar $\mathrm{Fe}$ : DIP ratio in the upper $3 \mathrm{~cm}$ of the sediment at the deep anoxic stations D, E, F (2008) varied between 0.09 and 0.22 . Thus, ca. $5-10 \%$ of the pore water DIP could 

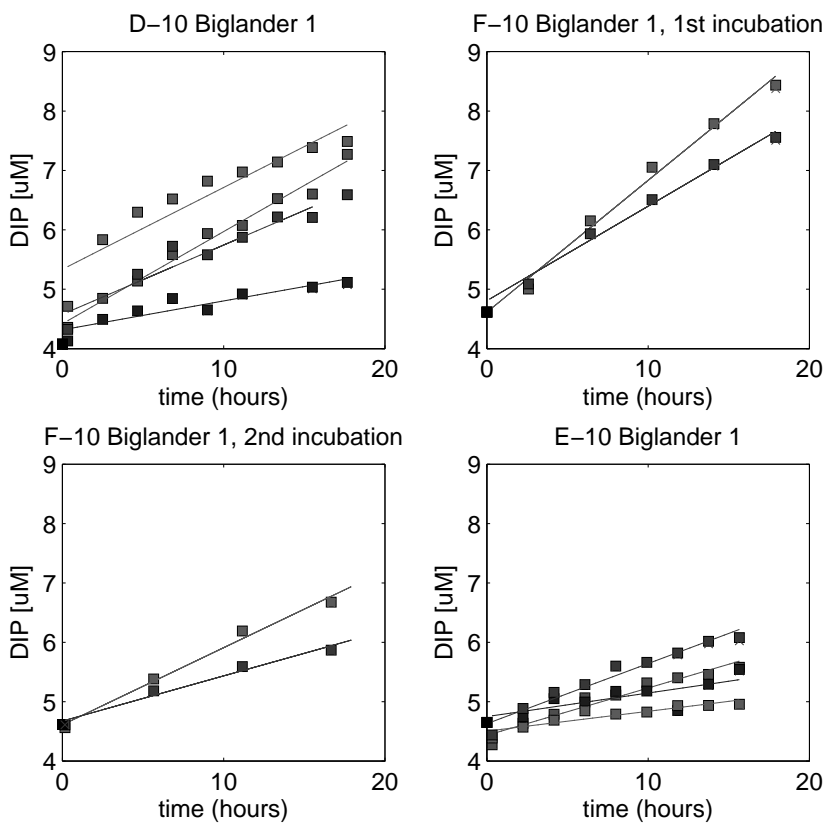

Fig. 6. Examples of evolution of the DIP concentration with time in chambers from the anoxic stations (D, E, F) on the 2010 cruise. The different shades of grey indicate different chambers. A full thin line means that the slope of the linear regression was used to calculate the flux.

be scavenged by $\mathrm{Fe}$ (III) upon oxygenation of the bottom water at these sites. However, this is probably an underestimate of the immobilisation of DIP which would occur upon oxygenation, since there are also other mechanisms responsible for retention of $\mathrm{P}$ in oxidised sediment such as bacterial accumulation of poly-phosphate (Gächter and Meyer, 1993; Sannigrahi and Ingall, 2005). Also, on longer timescales, the deposition of ferric iron to the sediments would increase upon a positive redox turnover of the sub-halocline water mass as the rate of pelagic iron reduction would decrease.

\subsection{Benthic P fluxes in the Baltic Proper}

To categorise the measured DIP fluxes with regard to oxygen condition and water depth, they were divided into three groups (modified after Mort et al., 2010; Jilbert et al., 2011); group 1 include fluxes from permanently oxic bottoms in the depth range of 30-70 m; group 2 include fluxes from bottoms where oxygen conditions can oscillate between oxic, hypoxic and anoxic conditions in the depth range 75-90 m; and group 3 include fluxes from permanently anoxic bottoms (i.e., anoxic since the latest Baltic Sea water exchange) in the depth range 124-210 m. Mean DIP fluxes for the three groups are presented in Table 2.

The DIP flux in the EGB generally increased with decreasing bottom water oxygen concentration or with increasingly reducing conditions (Figs. 7 and 8), which means that the DIP flux increased with increasing water depth. This is con- sistent with studies in open sea and coastal areas of the Gulf of Finland (Pitkänen et al., 2001; Lehtoranta and Heiskanen, 2003; Viktorsson et al., 2012), and with the relation between hypoxic/anoxic area and the Baltic $\mathrm{P}$ pool size, reported by Conley et al. (2002). However, the increase of benthic DIP flux with increasing water depth was not continuous, but rather increased stepwise from oxic to anoxic bottoms as DIP fluxes from group 1 and 2 sediments were rather similar, but substantially lower than the DIP fluxes from group 3 sediments (Fig. 7). The finding of relatively higher DIP fluxes from permanently anoxic sediments is in contrast to Jilbert et al. (2011) who estimated benthic DIP fluxes from pore water profiles and reported highest DIP effluxes from oxic- seasonally hypoxic sediments above or close to the permanent halocline (i.e., comparable to group 1 and 2 in the present study) in the Baltic proper and Gulf of Finland. Mort et al. (2010) similarly inferred a notably higher DIP efflux from the pore water DIP profile in sediment from a hypoxic station (BY2) in the Arkona Basin (44 m water depth) than from the permanently anoxic BY 31 and BY 29 sites in the northern Baltic proper. Such high DIP effluxes from relatively shallow seasonally hypoxic sediments are likely an effect of the remobilisation of temporary $\mathrm{P}$ sinks which are formed, and only stable, under oxic conditions (e.g., Mortimer, 1942; Gächter and Meyer, 1993). Thus, a seasonal transition from oxic to hypoxic bottom water conditions is likely to result in a non-steady-state and sharp increase in the benthic efflux of DIP from the sediment (Sundby et al., 1986; Belias et al., 2007; Schneider, 2011). In the present study, too few measurements during seasonal bottom water hypoxia/anoxia may have been conducted to capture this effect. On the other hand, some of the DIP flux estimations from shallow sediments in Jilbert et al. (2011) are questionable as the highest effluxes of DIP (0.6-0.8 mmol DIP m $\left.{ }^{-2} \mathrm{~d}^{-1}\right)$ were reported from the sediments overlain by oxic bottom water at the time of sampling. This counter intuitive result may be due to the inherent difficulty to extract pore water from oxic sediments with sufficiently high vertical resolution to be able to infer diffusive benthic DIP fluxes from the data (Sundby et al., 1986, 1992). With a too coarse vertical resolution of the pore water DIP gradient in oxygenated sediment, the surface zone where DIP is scavenged may have been obscured, and the calculated diffusive DIP flux may have been trapped in the surface oxygenated scavenging zone of the sediment. Thus, the 0.5 $1 \mathrm{~cm}$ resolution used by Jilbert et al. (2011) may have been too coarse and may, therefore, have resulted in overestimations of the benthic DIP efflux at oxic stations, which could explain the discrepancy with the results in the present study. This is an example of the advantage with determining fluxes from in situ incubations rather than from pore water gradients (Tengberg et al., 1995; Viollier et al., 2003).

Our DIP fluxes from permanently anoxic (group 3) sediments averaged $0.376 \mathrm{mmol} \mathrm{DIP} \mathrm{m}^{-2} \mathrm{~d}^{-1}$. This value is close to the average DIP flux measured in situ with German benthic landers in the anoxic part of the EGB (S. Sommer, personal 


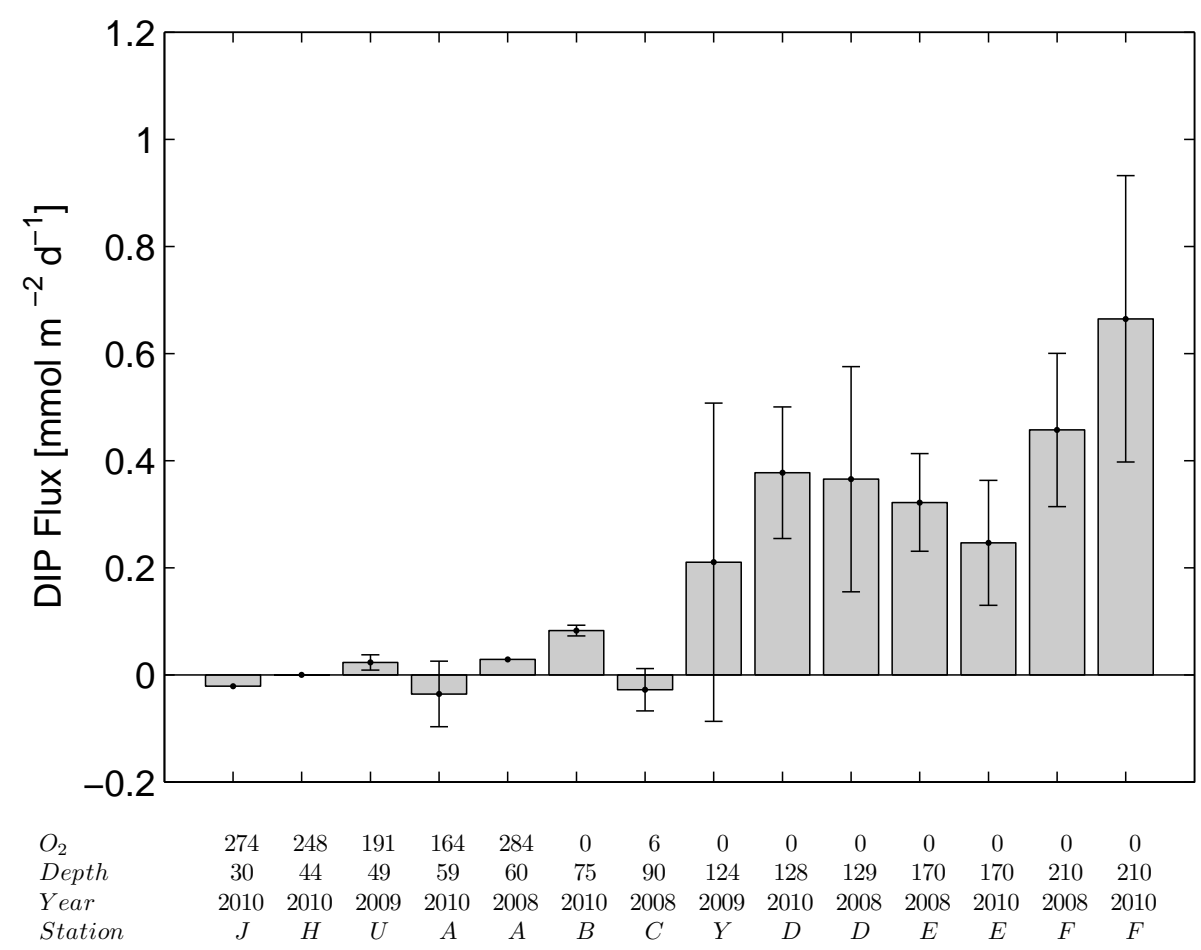

Fig. 7. Benthic DIP effluxes and up-take rates presented as station averages from each year. Error bars indicate $95 \%$ confidence interval, and its magnitude was mostly related to sediment spatial variability. The fluxes are sorted after bottom depth, with the shallowest station to the left and increasing bottom depth to the right. The labels on the $\mathrm{x}$-axis are from top to bottom; bottom water oxygen concentration in $\mu \mathrm{M}$, measured at the start of the incubation inside the chambers; bottom depth in m; year of sampling; and station name.

Table 2. Mean values of the DIP flux $\left(\mathrm{mmol} \mathrm{m}^{-2} \mathrm{~d}^{-1}\right)$ for the different depth ranges and bottom with oxic, hypoxic and anoxic bottom water (BW) conditions. Standard deviation $(\sigma)$, confidence interval (CI) and number of incubations $(n)$ are given in the last three columns.

\begin{tabular}{lcccccrr}
\hline \multicolumn{1}{c}{ Group, (Stations) } & $\begin{array}{c}\text { Depth } \\
\text { range }\end{array}$ & $\begin{array}{c}\text { Bottom } \\
\text { type }\end{array}$ & $\mathrm{BW} \mathrm{O}_{2}$ & $\begin{array}{c}\text { DIP flux } \\
\text { average }\end{array}$ & $\sigma$ & CI & $n$ \\
\hline 1 (A-08, U-09, J-10, H-10, A-10) & $30-60 \mathrm{~m}$ & T, E & $118-278$ & -0.003 & 0.040 & 0.025 & 10 \\
2 (C-08, B-10) & $75-90 \mathrm{~m}$ & A, T & $0-10$ & 0.027 & 0.068 & 0.067 & 4 \\
3 (D, E, F (-08,-10), Y-09) & $124-210 \mathrm{~m}$ & A & 0 & 0.376 & 0.214 & 0.082 & 26 \\
\hline
\end{tabular}

communication, 2012), but in the upper range (Mort et al., 2010; Jilbert et al., 2011) or considerably higher (Hille et al., 2005) than previous DIP flux modelling based on ex situ pore water gradients in comparable sediments in the Baltic Sea. This may partly be explained by seasonal differences as sampling by Jilbert et al. (2011) and Hille et al. (2005) was conducted in May-June when the vertical particulate organic C (POC) flux is generally lower than in AugustSeptember (Leipe et al., 2008), when our measurements were performed. However, there is an important dampening of the variability of process rates when the process passes through the sediment. Hence, the seasonal variability of the vertical POC flux to the sea-floor is much larger than the variability of the benthic DIP flux, partly because diffusion is slow; there is a time lag for bacteria to react to input of new organic matter; and the input flux is often (especially on oxic bottoms with fauna) mixed down into the sediment. Still, our fluxes from anoxic bottoms may represent the peak ones during the seasonal cycle.

Fluxes derived ex situ from pore water DIP profiles in sediments underlying anoxic bottom water have been found to be lower than those based on incubations, and especially than those based on in situ incubations (see discussions in Tengberg et al., 1995; Viktorsson et al., 2012). One reason for this is the difficulty to obtain sufficiently high vertical resolution of the pore water gradient, especially in organicrich anoxic Baltic sediments, to be able to calculate a correct diffusive flux. Contrary to sediments underlying oxygenated bottom water, a coarse vertical resolution of the pore water gradient in sediments underlying anoxic bottom water leads to an underestimation of the steepness of the gradient near the sediment-water interface and, hence, an 


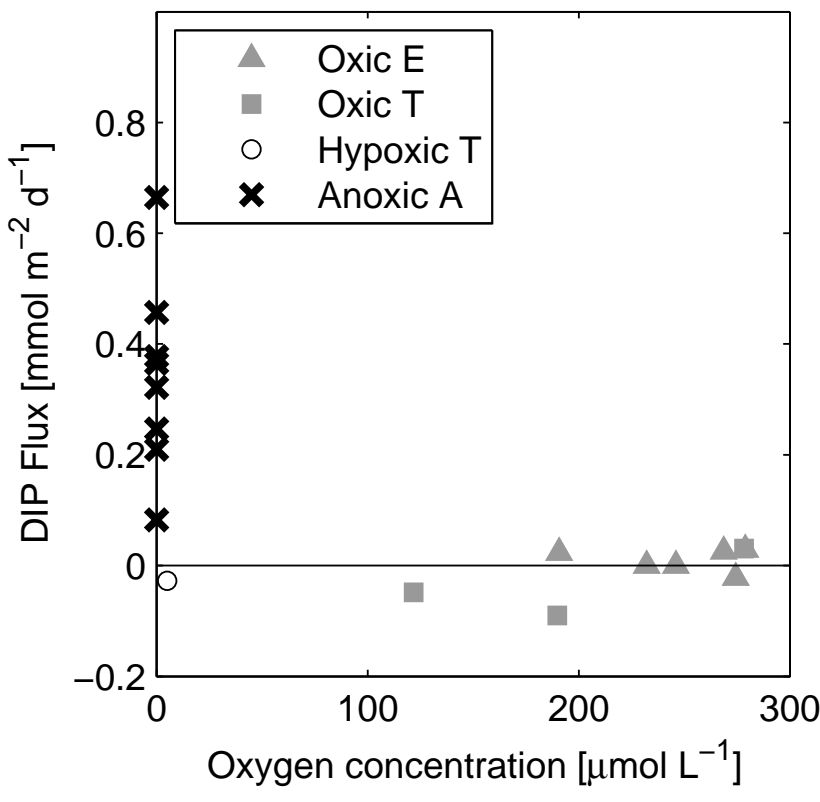

Fig. 8. DIP flux versus bottom water oxygen concentration; the latter was measured just before the start of the incubation inside the chambers. Fluxes are presented as mean values for each lander deployment.

underestimation of the benthic DIP flux. This may be another reason our fluxes are in the upper range (Mort et al., 2010; Jilbert et al., 2011) or considerably higher (Hille et al., 2005) than previous DIP flux estimates from anoxic Baltic proper bottoms. Since the spatial variability of bottom sediments in the Baltic Sea is known to be large, and the stations visited by Jilbert et al. (2011) and Mort et al. (2010) were located over different areas of the Baltic than the present study, an additional reason for the difference in anoxic DIP flux rates between those studies and the present one may be the difference in geographical location of stations in the three studies. The DIP fluxes reported by Hille et al. (2005) are exceptionally low compared to all other flux data, that we are aware of, from comparable Baltic sediments. We have at present no good explanation for this.

Benthic DIP fluxes have previously been measured during laboratory incubations of sediment cores from sites with oxic bottom water in the open Baltic Proper (Koop et al., 1990). These authors reported fluxes in the range -0.02 to $0.03 \mathrm{mmol} \mathrm{m}^{-2} \mathrm{~d}^{-1}$. Laima et al. (2001) reported an average DIP flux of $-0.010 \pm 0.004 \mathrm{mmolm}^{-2} \mathrm{~d}^{-1}$ from an oxic site in the open Arkona Basin. These fluxes are similar to fluxes measured in situ at oxic sites in the Gulf of Finland $\left(-0.01 \pm 0.08 \mathrm{mmol} \mathrm{m}^{-2} \mathrm{~d}^{-1}\right.$, Viktorsson et al., 2012), and to the flux range obtained at shallow oxic stations in this study (Table 2). The similarity between fluxes at Baltic oxic bottoms reported by Koop et al. (1990) and Laima et al. (2001) and this study is consistent with previous findings that DIP fluxes at such bottoms can be reliably measured by in situ as well as by ex situ incubations (Viktorsson et al., 2012).

DOP fluxes were measured at station $\mathrm{H}(44 \mathrm{~m})$ and D $(128 \mathrm{~m})$ during the measurement campaign in 2010. There were no significant DOP fluxes at the latter station, but at the shallower oxic site an average DOP efflux of $0.02 \mathrm{mmol} \mathrm{m}^{-2} \mathrm{~d}^{-1}$ was found. DOP mobilisation at station $\mathrm{H}$ may have been related to bioturbation by macrofauna (Ekeroth et al., 2012) presumably present in this sediment. At the same station and campaign, the simultaneous DIP flux was $0 \mathrm{mmolm}^{-2} \mathrm{~d}^{-1}$. DOP fluxes from oxic bottoms in the Baltic proper may, thus, be of similar magnitude or larger than DIP fluxes. However, we measured too few benthic DOP fluxes to be able to make a meaningful assessment of their importance in the Baltic proper based on the present dataset.

\subsection{Dependence of benthic $P$ recycling on deposition and degradation of organic matter}

The benthic DIP flux of this study was found to progressively increase along a gradient of increasing water depth and decreasing bottom water oxygen concentrations (Figs. 7 and 8). We also found that there was a positive correlation between the DIP flux and the organic carbon inventory of sediment at anoxic bottoms (Fig. 9). Since bottom water oxygen concentration decreased and sediment organic carbon inventory increased (Nilsson et al., 2013) with increasing water depth, we cannot from these correlations determine what caused the DIP flux to increase with increasing water depth. The benthic flux of dissolved inorganic carbon (DIC) was, therefore, correlated with the DIP flux. (The measurements of DIC fluxes will be fully presented in Nilsson et al., 2013). The DIC flux (in sediments where $\mathrm{CaCO}_{3}$ dissolution is negligible like in the Baltic) is a measure of organic carbon oxidation in sediment (Anderson et al., 1986), which is proportional to organic matter input to sediment (Henrichs, 1992). Relating DIP fluxes with DIC fluxes will, thus, help understand what controls the benthic DIP flux in aquatic systems, but has nevertheless only been made in a few previous studies (Ingall and Jahnke, 1997; McManus et al., 1997; Ingall et al., 2005; Kiirikki et al., 2006; Viktorsson et al., 2012). We found that the DIP and the DIC fluxes correlated well (by least square regression analysis) at anoxic stations $\left(R^{2}=0.65\right.$ and $p$ value $=0.016)$, but that they correlated poorly at oxic stations $\left(R^{2}=0.05\right.$ and $p$ value $=0.6$; Fig. 10). Our results, thus, suggest that the DIP flux from anoxic Baltic sediments was controlled by the deposition and degradation rate of organic matter in the sediment. A similar conclusion was made for anoxic bottoms in the Gulf of Finland (Viktorsson et al., 2012). For oxic sediments, our results confirm the classical paradigm of adsorption onto/coprecipitation with $\mathrm{Fe}(\mathrm{III})$ (Mortimer, 1942), but also bacterial accumulation of polyphosphate (Gächter et al., 1988) may have contributed to the removal of DIP from the pore water making the DIP flux small or even directed into the sediment at oxic stations 


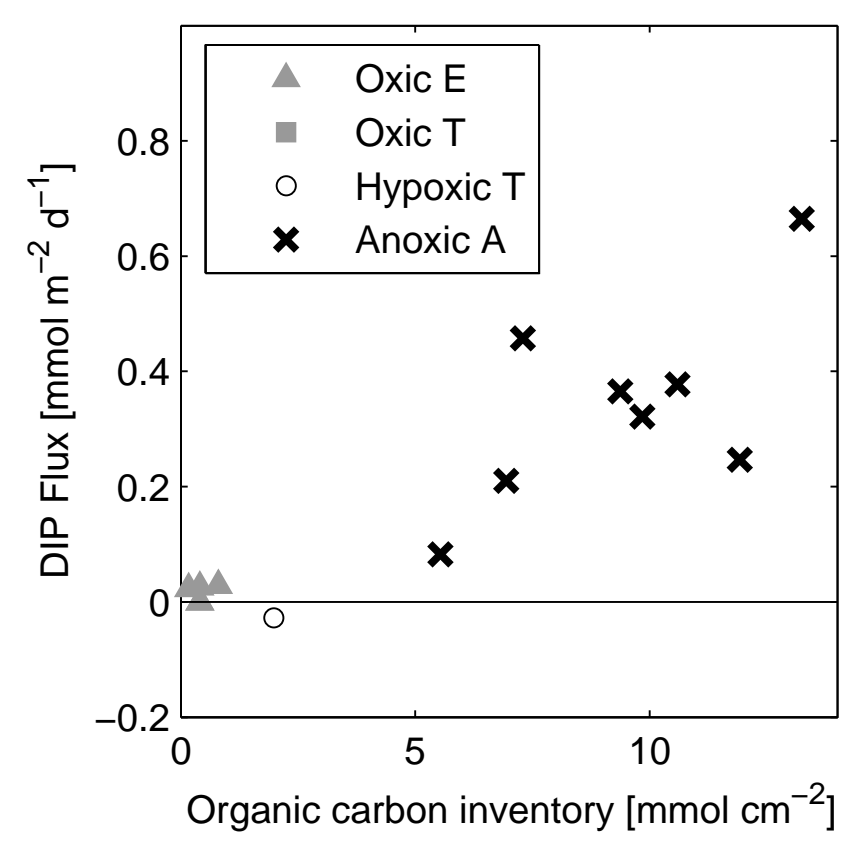

Fig. 9. DIP flux versus organic carbon inventory in the top $3 \mathrm{~cm}$ of the sediment. Fluxes are presented as mean values for each lander deployment.

(Fig. 8). This means that the benthic DIP flux was proportional to the diagenetic production of DIP in the pore water, as a result of remineralisation of organic $\mathrm{P}$, in anoxic bottoms. This is in contrast to oxic bottoms, where the abovementioned retention mechanisms restricted the DIP efflux. Our results cannot be used, and our aim was not, to elucidate if both or one of these "secondary" processes enhanced DIP retention in these shallow oxic Baltic proper sediments. The difference in DIP flux between oxic and anoxic bottoms cannot be explained simply by the generally lower rate of organic carbon oxidation (and organic $\mathrm{P}$ remineralisation) in the shallow oxic sediments, as the DIP flux was low even at moderately high organic carbon oxidation rates (Fig. 10). Thus, as long as there was enough oxygen in the bottom water, the DIP which was liberated to the pore water during remineralisation of organic $\mathrm{P}$ was not released to the bottom water in proportion to the organic $\mathrm{P}$ remineralisation rate.

The simultaneous measurements of benthic DIP and DIC fluxes in the same chambers allowed us to investigate $\mathrm{C}: \mathrm{P}$ ratios in the fluxes. The average $\mathrm{C}: \mathrm{P}$ ratio in fluxes at anoxic accumulation bottoms was $69 \pm 15$ (mean $\pm 1 \sigma$ ), which is well below the Redfield C:P ratio of $106: 1$ (Fig. 10). The average N:P ratio in fluxes $(3.8 \pm 2$, mean $\pm 1 \sigma)$ at anoxic bottoms (Hall et al., 2013) was also well below the Redfield $\mathrm{N}: \mathrm{P}$ ratio of $16: 1$. This shows that the anoxic flux in the EGB was $\mathrm{P}$ rich in relation to both $\mathrm{C}$ and $\mathrm{N}$. These results confirm previous observations (Ingall and Jahnke, 1997; Ingall et al., 2005; Kiirikki et al., 2006; Jilbert et al., 2011; Viktorsson et al., 2012) of low C:P ratios, well below that of

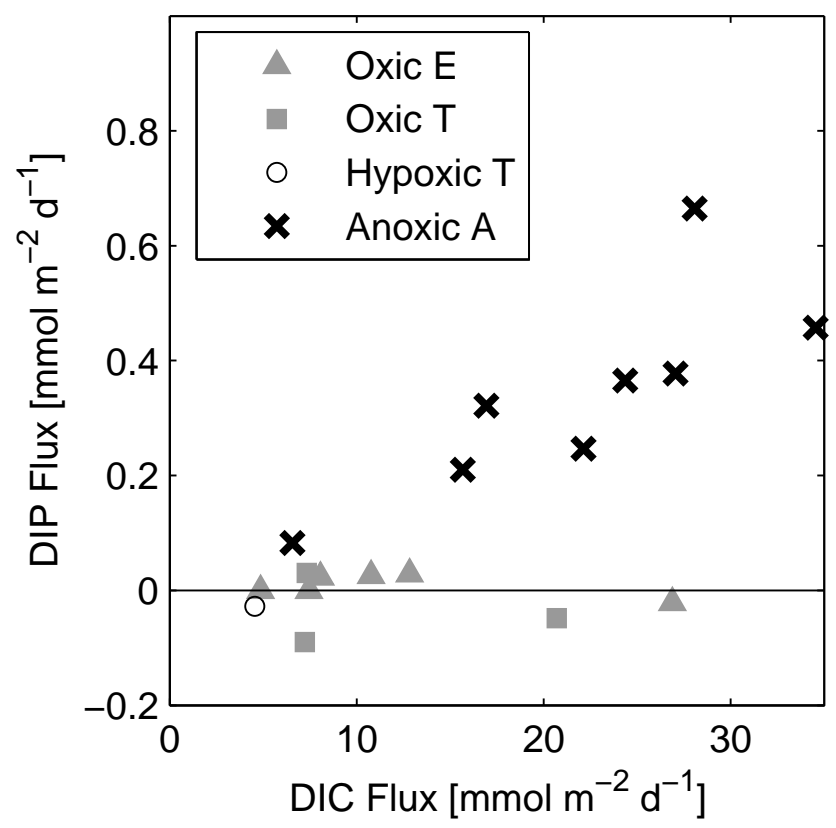

Fig. 10. DIP flux versus DIC flux. Fluxes are presented as mean values for each lander deployment.

fresh organic matter, in effluxes from permanently (or longterm) anoxic sediments. Previously published C: $P$ ratios include 30 (Ingall and Jahnke, 1997), 39 (Ingall et al., 2005), and 29 (Viktorsson et al., 2012). The low $\mathrm{C}: \mathrm{P}$ ratios in fluxes cannot be explained by disintegration of the abovementioned $\mathrm{P}$ sinks, as they should have long been depleted in long-term anoxic bottoms. One mechanistic explanation is that bacteria use enzymes (phosphatases) to cleave off phosphate groups from organic matter to increase the bioavailability of the organic matter C moiety (Steenbergh et al., 2011). The phenomenon of $\mathrm{P}$ rich fluxes has been called enhanced (in relation to carbon) $\mathrm{P}$ regeneration, and was first discussed for anoxic systems (Ingall and Jahnke, 1997; Ingall et al., 2005). Recently, it has been suggested that the enhanced P regeneration also occurs in sediment overlain by oxic water (Steenbergh et al., 2011).

There was no correlation between the DIP and DIC flux at the oxic stations and it was not possible to give a value of the average $C: P$ flux ratio since half of the DIP fluxes measured were negative (uptake of DIP and, thus, a $\mathrm{C}: \mathrm{P}$ ratio $\rightarrow \infty$ ). However, the $\mathrm{C}: \mathrm{P}$ ratio using only the positive DIP fluxes was $361 \pm 90($ mean $\pm 1 \sigma)$. This is much higher than the ratios at the anoxic stations and also than the Redfield ratio (Fig. 10). The obvious explanation for this is Fe(III) scavenging and bacterial assimilation as explained above. It is beyond the scope of this study to determine if the flux was $P$ rich at the anoxic bottoms due to anoxia per se or if the enhanced $\mathrm{P}$ regeneration occurred also in oxic sediments, but did not show up in the flux due to the high capacity of oxic 
sediments to retain DIP produced in the pore water during organic matter degradation (Steenbergh et al., 2011).

\subsection{Burial rates and burial efficiency}

Long-term removal of $\mathrm{P}$ from biogeochemical cycling in the sea takes place through burial in sediment. Burial rates can be calculated from sediment accumulation rates (SAR) and TP concentration at a depth in the sediment below which it does not change noticeably. Sediment accumulation rates in the EGB are highly spatially variable, ranging from 10.5 to $527 \mathrm{~g} \mathrm{~m}^{-2} \mathrm{yr}^{-1}$ with the highest rates in the northeastern part of the EGB (Hille et al., 2006). This high variability in sediment accumulation rate is reflected in the TP burial rates, because the TP content at depth in sediment was less variable than the sediment accumulation rate. Using the mean sediment accumulation rate of $129 \mathrm{~g} \mathrm{~m}^{-2} \mathrm{yr}^{-1}$ found by (Hille et al., 2006) and a sediment TP concentration of $30 \mu \mathrm{molg} \mathrm{g}^{-1}$, which was the measured concentration at depth in the sediment cores from this study, we calculated a TP burial rate of $0.011 \mathrm{mmolm}^{-2} \mathrm{~d}^{-1}$. This is similar to the TP burial rate calculated by Mort et al. (2010) for a site (the so called Northern Gotland site) in the Northern Baltic Proper $\left(0.018 \mathrm{mmolm}^{-2} \mathrm{~d}^{-1}\right)$, and the mean TP burial rate given by Hille et al. (2005) for the EGB $\left(0.018 \mathrm{mmolm}^{-2} \mathrm{~d}^{-1}\right)$. Hille et al. (2005) refer to this as the net TP deposition rate. Due to the highly variable sediment accumulation rate in the EGB, our TP burial rate calculation is very uncertain. Using the minimum and maximum sediment accumulation rates given by Hille et al. (2006) yield TP burial rates in the range of $0.0086-0.043 \mathrm{mmol} \mathrm{m}^{-2} \mathrm{~d}^{-1}$. Another source of uncertainty is the underlying assumption in our approach that the decreasing TP concentration with depth in the sediment is solely a result of $\mathrm{P}$ remineralisation, but not a result of a temporally increasing sedimentation rate during recent decades. Thus, we can widen the TP burial range by assuming that the TP concentration at $2 \mathrm{~cm}$ sediment depth for stations $\mathrm{E}$ and $\mathrm{F}$ represents the more contemporary burial TP concentration. This would give a maximum burial rate of $0.051 \mathrm{mmolm}^{-2} \mathrm{~d}^{-1}$. For the anoxic bottoms (>124 m) of our study the total input (or gross sediment deposition rate) of $\mathrm{P}$ to the sediment was calculated as the sum of our average measured DIP efflux $\left(0.376 \pm 0.214 \mathrm{mmolm}^{-2} \mathrm{~d}^{-1}\right)$ and the TP burial rate. Through this mass balance approach, and using the full range of TP burial rates (i.e., $0.0086-0.051 \mathrm{mmol} \mathrm{m}^{-2} \mathrm{~d}^{-1}$ ), a total input of $\mathrm{P}$ to the sediment in the anoxic part of the EGB of $0.38-0.43 \mathrm{mmol} \mathrm{m}^{-2} \mathrm{~d}^{-1}$ was calculated. The burial efficiency, i.e., the fraction of the $\mathrm{P}$ input to sediment which underwent long-term burial, thus, lie within $0.2-12 \%$. Using the mean TP burial rate given by Hille et al. (2005) for the deep part of the EGB $\left(0.018 \mathrm{mmolm}^{-2} \mathrm{~d}^{-1}\right)$, a TP concentration of $30 \mu \mathrm{molg}^{-1}$, and our average DIP efflux from anoxic bottoms, we calculated an average burial efficiency of $4 \%$. This low burial efficiency suggests that anoxic Baltic sediments are very efficient in recycling $\mathrm{P}$, and it is consistent with previous findings of enhanced $P$ recycling in anoxic marine sediments as discussed above. Our burial efficiency estimate in the EGB is well below that of $33 \%$ estimated for the EGB by Hille et al. (2005). These authors measured P burial rates, but likely overestimated the burial efficiency since they may have underestimated the DIP flux as explained above. This leads to a too low estimate of the input of $\mathrm{P}$ to sediment and, thus, to a too high burial efficiency.

\subsection{Internal DIP load in the Baltic Sea}

The size of the water column DIP pool is currently mostly controlled by the reflux of DIP from the bottom sediments (i.e., the internal load) although the only sources of new $\mathrm{P}$ is by external input from land and atmospheric deposition (Conley et al., 2002). It is possible to make an integrated estimate of the magnitude of the internal DIP load to the Baltic Proper based on our direct flux measurements. Using the average benthic DIP fluxes at anoxic bottoms, presented in Table 2, for group 3 sediments, an areal extrapolation of the internal DIP load to the water column of the anoxic Baltic proper was made for two time periods with different expansion of anoxia. The two periods used were 1960-1998 and 1999-2006, and the areas were calculated from the same data used by Hansson et al. (2011), but excluding the Gulf of Finland and the Gulf of Riga (M. Hansson, personal communication, 2013). The resulting total internal load for the period 1999-2006 was $152 \mathrm{kton} \mathrm{yr}^{-1}$ (Table 3). The internal P load from anoxic bottoms was estimated by Matthiesen (1998) to

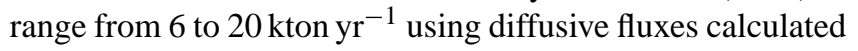
from pore water gradients at the BY 31 station (EGB) and a naturally laminated, muddy sediment area in the Baltic sea of $20000 \mathrm{~km}^{-2}$ (after Jonsson et al., 1990). Our 8-25 times higher estimate is partly due to the contemporary larger area of anoxic sediments in the Baltic proper. Also, at the time of sampling, the sediment used for the former estimate was hypoxic, rather than fully anoxic (Matthiesen, 1998), which according to our results may explain that the DIP efflux was considerably below the range presented for anoxic sediments in the present study. The direct measurements of benthic DIP fluxes under ambient natural conditions provide a basis for better extrapolation of the integrated internal DIP load to the Baltic proper than previous attempts. It should be noted, however, that our measurements were carried out during a season (August-September) when the vertical POC flux in the water column is relatively high (Leipe et al., 2008). As the DIP efflux from anoxic sediments was largely driven by the input of organic matter to the sediment (see above and Conclusions), our annual internal load calculation may be slightly overestimated.

The internal DIP load was also calculated for the period 1960-1998 using the mean value for the anoxic area given in Table 3 calculated from the data in Hansson et al. (2011) for that time period (M. Hansson, personal communication, 
Table 3. Calculated internal DIP load to the Baltic Proper, based on in situ measured benthic DIP fluxes (this study) and the areal extent of anoxia based on the data from Hansson et al. (2011) for the two time periods 1999-2006 and 1960-1998 and recalculated for only the Baltic proper.

\begin{tabular}{ccccccc}
\hline Time period & Redox & Area $\left(\mathrm{km}^{2}\right)$ & \multicolumn{2}{c}{ Flux $\left(\mathrm{mmol} \mathrm{m}^{-2} \mathrm{~d}^{-1}\right)$} & \multicolumn{2}{c}{ Load $\left(\mathrm{kton} \mathrm{yr}^{-1}\right)$} \\
& condition & & mean & $\sigma$ & mean & $\sigma$ \\
\hline $1960-1998$ & anoxic & $14695(7 \%)$ & 0.376 & 0.214 & 62 & 35 \\
$1999-2006$ & anoxic & $35688(17 \%)$ & 0.376 & 0.214 & 152 & 86 \\
\hline
\end{tabular}

2013). An assumption in this calculation is that the inventory of organic matter in the sediment was not significantly different in 1960-1998 compared to the later time period for which we calculated internal load. The internal load was

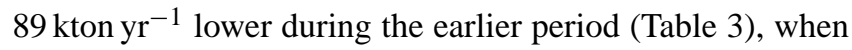
the average anoxic area covered $7 \%$ of the total bottom area in the Baltic proper, compared to $17 \%$ of the total Baltic proper area during the later period.

Our estimate of the annual internal DIP load for the period 1999-2006 is 9 times higher than the average external load of

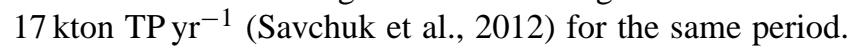
For the earlier period (1960-1998), the internal DIP load was 2.6 times higher than the average external input of TP during that time (Savchuk et al., 2012). External sources supply new $\mathrm{P}$ to the system while the internal load is a regeneration process of $\mathrm{P}$ already present. Hence, the internal and external loads are not directly equivalent. However, the above comparison of external and internal $\mathrm{P}$ loads clearly highlights the dominating role of sediments as DIP regeneration catalysts, rather than P sinks in the Baltic Proper, and confirms the positive feedback (or the vicious circle Vahtera et al., 2007) between enhanced phytoplankton production, higher rates of organic matter sedimentation, spread of anoxia, stimulated benthic P flux, and intensified cyanobacterial blooms and $\mathrm{N}$ fixation. Further efforts to find cost-efficient solutions to decrease the internal DIP load in the Baltic should, thus, be seriously considered.

\section{Conclusions}

This study is the first to report in situ measured benthic DIP fluxes in the open Baltic proper. It also provides the most comprehensive dataset of benthic DIP fluxes in the Baltic proper existing to date. One general finding of this study is that the DIP flux in the EGB increased with increasing water depth and with decreasing bottom water oxygen concentration. The average DIP flux at anoxic bottoms $(>124 \mathrm{~m})$ was $0.376 \pm 0.214 \mathrm{mmolm}^{-2} \mathrm{~d}^{-1}$ and $0.003 \pm 0.040 \mathrm{mmolm}^{-2} \mathrm{~d}^{-1}$ for oxic bottoms stations. The in situ measured fluxes were in the upper range or much higher than previous ex situ estimated fluxes at anoxic bottoms. This difference may be explained by uncertainties with estimating fluxes from pore water gradients (e.g., Sundby et al., 1986) and difficulties in maintaining in situ conditions when working ex situ (Tengberg et al., 1995; Viktorsson et al., 2012; Viollier et al., 2003). In contrast to the more or less strong mismatch with ex situ measurements for anoxic conditions, our DIP fluxes agree with previous estimates of DIP fluxes at oxic bottoms in the Baltic based on incubations (Koop et al., 1990; Viktorsson et al., 2012; Laima et al., 2001). We suggest that previous ex situ estimates of anoxic benthic DIP fluxes in the open Baltic proper often may be underestimates, probably mostly due to insufficient vertical resolution of pore water gradients.

The DIP flux was positively correlated with the organic carbon inventory of sediment. The DIP flux also correlated well with the DIC flux at anoxic stations, but these fluxes correlated poorly at oxic stations. The positive correlation between DIP and DIC fluxes suggests that the benthic DIP flux at anoxic bottoms in the Baltic proper is controlled by rates of deposition and degradation of organic matter. This, in turn, indicates that the vicious circle (Vahtera et al., 2007) is not only triggered by increased sedimentation of organic matter, causing expanded oxygen depletion which causes increased P fluxes from sediment, but that increased sedimentation of organic matter per se causes a higher benthic $P$ flux. This, in turn, stimulates cyanobacterial growth and blooms, which causes higher export of organic matter from surface to bottom making the benthic $\mathrm{P}$ flux higher, and so on.

The flux from anoxic sediment was very $\mathrm{P}$ rich in relation to both $\mathrm{C}$ and $\mathrm{N}$, and the average $\mathrm{C}: \mathrm{P}$ ratio in fluxes from anoxic accumulation bottoms was $69 \pm 15($ mean $\pm 1 \sigma)$, which is well below the Redfield $\mathrm{C}: \mathrm{P}$ ratio of $106: 1$. At oxic stations, however, the $\mathrm{C}: \mathrm{P}$ flux ratio was much higher than the Redfield ratio, consistent with well-known $\mathrm{P}$ retention mechanisms associated with $\mathrm{Fe}$ and bacteria in oxidised sediment.

Using a benthic mass balance approach, a burial efficiency of $0.2-12 \%$ was calculated for the anoxic part of the EGB, which suggests that anoxic Baltic sediments are very efficient in recycling deposited $\mathrm{P}$.

Based on the measured DIP fluxes from anoxic bottoms, an internal DIP load to the Baltic proper water column of $152 \mathrm{kton} \mathrm{yr}^{-1}$ was calculated for the period 1999-2006 and of $63 \mathrm{kton} \mathrm{yr}^{-1}$ for the period 1960-1998 (assuming the average benthic DIP flux at anoxic bottoms has not changed 
in-between these two time periods). Thus, the more recent

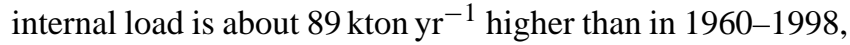
which is due to the larger area of sediments underlying anoxic water in the later period. Our estimated internal load for 1999-2006 is 9 times higher than the most recent estimate of the average external load for the same time period. This clearly highlights the dominating role of sedimentary recycling in the Baltic proper $\mathrm{P}$ cycle.

Acknowledgements. We thank O. Pfannkuche and S. Sommer at GEOMAR, Kiel, Germany for inviting us to participate on the R/V Alkor cruise in September 2009; A. Tengberg, D. Atamanchuk, E. Almroth Rosell and Elina Cuellar for assistance during expeditions; E. Almroth Rosell for Fe and Mn determinations; the staff of the Chemical Laboratory at the Department of Ecology, Environment and Plant Sciences, Stockholm University, for $\mathrm{P}$ determinations; and the captains and crew on R/V Skagerak and R/V Alkor for skilful help at sea. We are also grateful to Martin Hansson at the Swedish Meteorological and Hydrological Institute for providing us with estimates of anoxic areas in the Baltic proper. This study was supported financially by HYPOX (In situ monitoring of oxygen depletion in hypoxic ecosystems of coastal and open seas, and land-locked water bodies) funded by the European Commission Seventh Framework programme (FP/2007-2013) under grant agreement number 226213, the Swedish Research Council (VR), SENSEnet (International sensor development network) - a Marie Curie Initial Training Network (ITN) funded by the European Commission Seventh Framework Programme under grant agreement number 237868, the Tellus Research Platform at University of Gothenburg, and the Swedish Environmental Protection Agency (NV) through the BOX project.

Edited by: C. P. Slomp

\section{References}

Almroth, E., Tengberg, A., Andersson, J. H., Pakhomova, S., and Hall, P. O.: Effects of resuspension on benthic fluxes of oxygen, nutrients, dissolved inorganic carbon, iron and manganese in the Gulf of Finland, Baltic Sea, Cont. Shelf. Res., 29, 807818, doi:10.1016/j.csr.2008.12.011, 2009.

Anderson, L. G., Hall, P. O. J., Iverfeldt, A., Rutgers van der Loeff, M. M., Sundby, B., and Westerlund, S. F. G.: Benthic Respiration Measured by Total Carbonate Production, Liminol. Oceanogr., 31, 319-329, http://www.jstor.org/stable/2836808, 1986.

Barnett, P. R. O., Watson, J., and Connelly, D.: A Multiple Corer for Taking Virtually Undisturbed Samples from Shelf, Bathyal and Abyssal Sediments, Oceanol Ac., 7, 399-408, 1984.

Belias, C., Dassenakis, M., and Scoullos, M.: Study of the N, P and $\mathrm{Si}$ fluxes between fish farm sediment and seawater. Results of simulation experiments employing a benthic chamber under various redox conditions, Mar. Chem., 103, 266-275, doi:10.1016/j.marchem.2006.09.005, 2007.

Carman, R. and Cederwall, H.: Sediments and Macrofauna in the Baltic Sea - Characteristics, Nurient Contents and Distribution, Ecological Studies, 148, 289-327, Springer-Verlag, Berlin Heidelberg, 2001.
Conley, D. J., Humborg, C., Rahm, L., Savchuk, O. P., and Wulff, F.: Hypoxia in the Baltic Sea and basin-scale changes in phosphorus biogeochemistry, Environ. Sci. Technol., 36, 5315-5320, 2002.

Eilola, K., Meier, H. E. M., and Almroth, E.: On the dynamics of oxygen, phosphorus and cyanobacteria in the Baltic Sea; A model study, J. Marine Syst., 75, 163-184, 2009.

Ekeroth, N., Lindström, M., Blomqvist, S., and Hall, P. O.: Recolonisation by Macrobenthos Mobilises Organic Phosphorus from Reoxidised Baltic Sea Sediments, Aquat. Geochem., 18, 499-513, doi:10.1007/s10498-012-9172-5, 2012.

Elmgren, R.: Understanding human impact on the Baltic ecosystem: Changing views in recent decades, Ambio, 30, 222-231, 2001.

Emeis, K. C., Struck, U., Leipe, T., Pollehne, F., Kunzendorf, H., and Christiansen, C.: Changes in the $\mathrm{C}, \mathrm{N}, \mathrm{P}$ burial rates in some Baltic Sea sediments over the last 150 years - relevance to $\mathrm{P}$ regeneration rates and the phosphorus cycle, Mar. Geol., 167, 43$59,2000$.

Finni, T., Kononen, K., Olsonen, R., and Wallström, K.: The history of cyanobacterial blooms in the Baltic Sea, Ambio, 30, 172-178, 2001.

Gächter, R. and Meyer, J. S.: The Role of Microorganisms in Mobilization and Fixation of Phosphorus in Sediments, Hydrobiologia, 253, 103-121, 1993.

Gächter, R., Meyer, J. S., and Mares, A.: Contribution of Bacteria to Release and Fixation of Phosphorus in lake sediments, Liminol. Oceangr., 33, 1542-1558, 1988.

Granéli, E., Wallström, K., Larsson, U., Granéli, W., and Elmgren, R.: Nutrient limitation of primary production in the Baltic Sea area, Ambio, 19, 142-151, 1990.

Grasshoff, K., Kremling, K., and Ehrhardt, M. (Eds.): Methods of Seawater Analysis, WILEY-VCH, 1999.

Gunnars, A. and Blomqvist, S.: Phosphate exchange across the sediment-water interface when shifting from anoxic to oxic conditions - an experimental comparison of freshwater and brackish-marine systems, Biogeochemistry, 37, 203-226, 1997.

Gunnars, A., Blomqvist, S., Johansson, P., and Andersson, C.: Formation of $\mathrm{Fe}(\mathrm{III})$ oxyhydroxide colloids in freshwater and brackish seawater, with incorporation of phosphate and calcium, Geochim. Cosmochim. Ac., 66, 745-758, doi:10.1016/S00167037(01)00818-3, 2002.

Håkanson, L. and Jansson, M.: Principles of Lake Sedimentology, The Blackburn Press, 2002.

Hagström, A., Azam, F., Kuparinen, J., and Zweifel, U.-L.: Pelagic Plankton Growth and Resource Limitations in the Baltic Sea, Ecological Studies, 148, Springer-Verlag Berlin Heidelberg, 2001.

Hall, P., Kononets, M., Viktorsson, L., Dalsgaard, T., De Brabandere, L., Sommer, S., and Pfannkuche, O.: Recycling and removal of fixed nitrogen in sediments of the central Baltic Sea, in preparation, 2013.

Hansson, M., Andersson, L., and Axe, P.: Areal Extent and Volume of Anoxia and Hypoxia in the Baltic Sea, 1960-2011, Tech. Rep. 0283-1112, SMHI Swedish Meteorological and Hydrological Institute, 2011.

HELCOM: The Fourth Baltic Sea Pollution Load Compilation (PLC-4) Balt. Sea Environ. Proc. No. 93, 2004.

HELCOM: The Fifth Baltic Sea Pollution Load Compilation (PLC5) Balt. Sea Environ. Proc. No. 128, 2011. 
Henrichs, S. M.: Early diagenesis of organic matter in marine sediments: progress and perplexity, Mar. Chem., 3, 119-149, doi:10.1016/0304-4203(92)90098-U, 1992.

Hille, S., Nausch, G., and Leipe, T.: Sedimentary deposition and reflux of phosphorus $(\mathrm{P})$ in the Eastern Gotland Basin and their coupling with $\mathrm{P}$ concentrations in the water column, Oceanologia, 47, 663-679, 2005.

Hille, S., Leipe, T., and Seifert, T.: Spatial variability of recent sedimentation rates in the Eastern Gotland Basin (Baltic Sea), Oceanologia, 48, 297-317, 2006.

Ingall, E. and Jahnke, R.: Influence of water-column anoxia on the elemental fractionation of carbon and phosphorus during sediment diagenesis, Mar. Geol., 139, 219-229, 1997.

Ingall, E., Kolowith, L., Lyons, T., and Hurtgen, M.: Sediment carbon, nitrogen and phosphorus cycling in an anoxic fjord, Effingham Inlet, British Columbia, Am. J. Sci., 305, 240-258, 2005.

Jilbert, T., Slomp, C. P., Gustafsson, B. G., and Boer, W.: Beyond the Fe-P-redox connection: preferential regeneration of phosphorus from organic matter as a key control on Baltic Sea nutrient cycles, Biogeosciences, 8, 1699-1720, doi:10.5194/bg-8-16992011, 2011.

Jonsson, P., Carman, R., and Wulff, F.: Laminated Sediments in the Baltic - a Tool for Evaluating Nutrient Mass Balances, Ambio, 19, 152-158, 1990.

Kiirikki, M., Lehtoranta, J., Inkala, A., Pitkänen, H., Hietanen, S., Hall, P. O. J., Tengberg, A., Koponen, J., and Sarkkula, J.: A simple sediment process description suitable for 3D-ecosystem modelling - Development and testing in the Gulf of Finland, J. Marine Syst., 61, 55-66, doi:10.1016/j.jmarsys.2006.02.008, 2006.

Kononets, M. Y., Pakhomova, S. V., Rozanov, A. G., and Proskurnin, M. A.: Determination of soluble iron species in seawater using ferrozine, J. Anal. Chem., 57, 586-589, 2002.

Koop, K., Boynton, W. R., Wulff, F., and Carman, R.: SedimentWater Oxygen and Nutrient Exchanges Along a Depth Gradient in the Baltic Sea, Mar. Ecol.-Prog. Ser., 63, 65-77, 1990.

Koroleff, F.: Methods of Seawater Analysis, chap. Determination of Phosphorus, 125-139, Verlag Chemie, 2nd Edn., 1983.

Krom, M. D., Kress, N., Brenner, S., and Gordon, L. I.: Phosphorus Limitation of Primary Productivity in the Eastern MediterraneanSea, Liminol. Oceangr., 36, 424-432, 1991.

Laima, M., Matthiesen, H., Christiansen, C., Lund-Hansen, L., and Emeis, K.: Dynamics of $\mathrm{P}, \mathrm{Fe}$ and $\mathrm{Mn}$ along a depth gradient in the SW Baltic Sea, Boreal Environ. Res., 6, 317-333, 2001.

Larsson, U., Hajdu, S., Walve, J., and Elmgren, R.: Baltic Sea nitrogen fixation estimated from the summer increase in upper mixed layer total nitrogen, Liminol. Oceangr., 46, 811-820, 2001.

Lehtoranta, J. and Heiskanen, A.: Dissolved iron: phosphate ratio as an indicator of phosphate release to oxic water of the inner and outer coastal Baltic Sea, Hydrobiologia, 492, 69-84, doi:10.1023/A:1024822013580, 2003.

Leipe, T., Harff, J., Meyer, M., Hille, S., Pollehne, F., Schneider, R., Kowalski, N., and Brügmann, L.: Sedimentary Records of Environmental Changes and Anthropogenic Impacts during the Past Decades, 395-439, John Wiley \& Sons, Inc., doi:10.1002/9780470283134.ch14, 2008.

Matthiesen, H.: Phosphate release from marine sediments: by diffusion, advection and resuspension, Ph.D. thesis, University of Aarhus, 1998.
McManus, J., Berelson, W. M., Coale, K. H., Johnson, K. S., and Kilgore, T. E.: Phosphorus regeneration in continental margin sediments, Geochim. Cosmochim. Ac., 61, 2891-2907, 1997.

Mort, H. P., Slomp, C. P., Gustafsson, B. G., and Andersen, T. J.: Phosphorus recycling and burial in Baltic Sea sediments with contrasting redox conditions, Geochim. Cosmochim. Ac., 74, 1350-1362, 2010.

Mortimer, C. H.: The exchange of dissolved substances between mud and water in lakes: III and IV, J. Ecol., 30, 147-201, 1942.

Nausch, G., Nehring, D., and Nagel, K.: Nutrient Concentrations, Trends and Their Relation to Eutrophication, 337-366, John Wiley and Sons, Inc., doi:10.1002/9780470283134.ch12, 2008.

Nilsson, M.: Benthic oxygen dynamics and biogenic matter turnover in the deep Arctic ocean, Master's thesis, Gothenburg University, 2008.

Nilsson, M., Kononets, M., Viktorsson, L., Almroth-Rosell, E., Atamanchuk, D., Roos, P., Pfannkuche, O., Sommer, S., and Hall, P.: Oxidation and burial of organic carbon in sediments of the central Baltic Sea, in preparation, 2013.

Pakhomova, S.: Rastvorennye formy zheleza i margantsa v vodnoi tolsche, osadkah i na granitse razdela voda-dno (Dissolved iron and manganese species in water column, sediments and at watersediment interface), Ph.D. thesis, Shirshov Institute of Oceanology, in Russian, 2005.

Peshkova, V. and Ovsyannikova, A.: Kolorimetricheskoye opredeleine margantsa formaldoximom (colorimetric determination of manganese with formaldoxyme), Zavodskaya Laboratoriya, 1937 (in Russian).

Pitkänen, H., Lehtoranta, J., and Raike, A.: Internal nutrient fluxes counteract decreases in external load: The case of the estuarial eastern Gulf of Finland, Baltic Sea, Ambio, 30, 195201, doi:10.1639/0044-7447(2001)030[0195:INFCDI]2.0.CO;2, 2001.

Poutanen, E. L. and Nikkilä, K.: Carotenoid pigments as tracers of cyanobacterial blooms in recent and post-glacial sediments of the Baltic Sea, Ambio, 30, 179-183, 2001.

Sannigrahi, P. and Ingall, E.: Polyphosphates as a source of enhanced $P$ fluxes in marine sediments overlain by anoxic waters: Evidence from P-31 NMR, Geochem. T., 6, 52-59, 2005.

Savchuk, O. P., Eilola, K., Gustafsson, B. G., Medina, M. R., and Ruoho-Airola, T.: Long-term reconstruction of nutrient loads to the Baltic Sea, 1850-2006, Technical report, Baltic Nest Institute, 2012.

Schindler, D. W.: Evolution of Phosphorus Limitation in Lakes, SCIENCE, 195, 260-262, 1977.

Schneider, B.: PO4 release at the sediment surface under anoxic conditions: a contribution to the eutrophication of the Baltic Sea?, Oceanologia, 53, 415-429, 2011.

Schneider, B., Nausch, G., Kubsch, H., and Petersohn, I.: Accumulation of total $\mathrm{CO} 2$ during stagnation in the Baltic Sea deep water and its relationship to nutrient and oxygen concentrations, Mar. Chem., 77, 277-291, 2002.

Ståhl, H., Tengberg, A., Brunnegård, J., and Hall, P. O. J.: Recycling and burial of organic carbon in sediments of the Porcupine Abyssal Plain, NE Atlantic, Deep-Sea Res. Pt. I, 51, 777-791, 2004.

Steenbergh, A., Bodelier, P., Hoogveld, H., Slomp, C., and Laanbroek, H.: Phosphatases relieve carbon limitation of microbial activity in Baltic Sea sediments along a redox-gradient, Liminol. 
Oceangr., 56, 2018-2026, 2011.

Stigebrandt, A.: Physical Oceanography of the Baltic Sea, Ecological Studies, 148, 19-74, Springer-Verlag, Berlin Heidelberg, 2001.

Stigebrandt, A. and Wulff, F.: A Model for the Dynamics of Nutrients and Oxygen in the Baltic Proper, J. Mar. Res., 45, 729-759, 1987.

Sundby, B., Anderson, L. G., Hall, P. O. J., Iverfeldt, A., Rutgers van der Loeff, M. M., and Westerlund, S. F. G.: The Effect of Oxygen on Release and Uptake of Cobalt, Manganese, Iron and Phosphate at the Sediment-Water Interface, Geochim. Cosmochim. Ac., 50, 1281-1288, 1986.

Sundby, B., Gobeil, C., Silverberg, N., and Mucci, A.: The phosphorus cycle in coastal marine sediments, Liminol. Oceangr., 37 , 1129-1145, 1992.

Tengberg, A., de Bovee, F., Hall, P., Berelson, W., Chadwick, D., Ciceri, G., Crassous, P., Devol, A., Emerson, S., Gage, J., Glud, R., Graziottini, F., Gundersen, J., Hammond, D., Helder, W., Hinga, K., Holby, O., Jahnke, R., Khripounoff, A., Lieberman, S., Nuppenau, V., Pfannkuche, O., Reimers, C., Rowe, G., Sahami, A., Sayles, F., Schurter, M., Smallman, D., Wehrli, B., and Wilde, P. D.: Benthic chamber and profiling landers in oceanography - A review of design, technical solutions and functioning, Prog. Oceanogr., 35, 253-294, doi:10.1016/00796611(95)00009-6, 1995.

Tengberg, A., Ståhl, H., Gust, G., Muller, V., Arning, U., Andersson, H., and Hall, P. O. J.: Intercalibration of benthic flux chambers I. Accuracy of flux measurements and influence of chamber hydrodynamics, Prog. Oceanogr., 60, 1-28, 2004.

Tengberg, A., Hovdenes, J., Andersson, J. H., Brocandel, O., Diaz, R., Hebert, D., Arnerich, T., Huber, C., Körtzinger, A., Khripounoff, A., Rey, F., Rönning, C., Sommer, S., and Stangelmayer, A.: Evaluation of a life time based optode to measure oxygen in aquatic systems, Liminol. Oceangr.-Meth., 4, 7-17, 2006.
Vahtera, E., Conley, D. J., Gustafsson, B. G., Kuosa, H., Pitkänen, H., Savchuk, O. P., Tamminen, T., Viitasalo, M., Voss, M., Wasmund, N., and Wulff, F.: Internal ecosystem feedbacks enhance nitrogen-fixing cyanobacteria blooms and complicate management in the Baltic Sea, Ambio, 36, 186-194, 2007.

Valderrama, J. C.: The simultaneous analysis of total nitrogen and total phosphorus in natural waters, Mar. Chem., 10, 109-122, doi:10.1016/0304-4203(81)90027-X, 1981.

Verardo, D. J., Froelich, P. N., and McIntyre, A.: Determination of Organic-Carbon and Nitrogen in Marine-Sediments Using the Carlo-Erba-Na-1500 Analyzer, Deep-Sea Res., 37, 157-165, 1990.

Viktorsson, L., Almroth-Rosell, E., Tengberg, A., Vankevich, R., Neelov, I., Isaev, A., Kravtsov, V., and Hall, P.: Benthic Phosphorus Dynamics in the Gulf of Finland, Baltic Sea, Aquat. Geochem., 18, 543-564, doi:10.1007/s10498-011-9155-y, 2012.

Viollier, E., Rabouille, C., Apitz, S., Breuer, E., Chaillou, G., Dedieu, K., Furukawa, Y., Grenz, C., Hall, P., Janssen, F., Morford, J., Poggiale, J.-C., Roberts, S., Shimmield, T., Taillefert, M., Tengberg, A., Wenzhäfer, F., and Witte, U.: Benthic biogeochemistry: state of the art technologies and guidelines for the future of in situ survey, J. Exp. Mar. Biol. Ecol., 285-286, 5-31, doi:10.1016/S0022-0981(02)00517-8, 2003.

Voss, M., Dippner, J. W., Humborg, C., Hardler, J., Korth, F., Neumann, T., Schernewski, G., and Venohr, M.: History and scenarios of future development of Baltic Sea eutrophication, Estuar. Coast. Shelf. S., 92, 307-322, doi:10.1016/j.ecss.2010.12.037, 2011.

Wu, J. F., Sunda, W., Boyle, E. A., and Karl, D. M.: Phosphate depletion in the western North Atlantic Ocean, Science, 289, 759762, 2000. 